doi:10.29285/actapinteriana.2018.4.89

\title{
A Szentföldi Kusztódia jeruzsálemi levéltárának története
}

\author{
Narcyz Klimas OFM \\ Terra Sancta College, 2, Keren Hayesod Street, P.O.B. 871, 9100801 Jerusalem, Israel \\ narcyzklimas141@hotmail.com
}

Klimas, N. (2018): A Szentföldi Kusztódia jeruzsálemi levéltárának története. History of the Archives of the Custody of the Holy Land in Jerusalem. Acta Pintériana, 4, 89-116.

Abstract: The Archives of the Custody of the Holy Land in Jerusalem is the Catholic organization in partibus infidelium, which, throughout the ages, has represented the Holy See. The majority of these Archives document the return of Catholicism to the Holy Land and can be helpful to learn the history of Catholics in the Holy Land and its neighboring countries. Its significance comes also from the fact that, as the Archives of the Custody of the Holy Land, it also collects historical documents from all the countries of the Middle East. Many important documents depict the process of recovering the holy sites from Muslims and allowing access to pilgrims coming to these places, as well as descriptions of everyday life of the friars and Christians who live in the Holy Land and the Middle East. The beginning of the Archives go back to Pope Gregory IX's bull and continues to the current time.

\section{Bevezetés}

A Szentföldi Kusztódia Levéltárának történetéröl alig találunk irodalmat. Az itt-ott elszórt történelmi jellegủ töredékek nem jelentenek elegendő segítséget, mert a bennük foglalt információk véletlenszerüek és felületesek. A kérdéssel először Leonhard Lemmens foglalkozott, és bár nem tudta teljesen rendszerezni a levéltárat, de előkészítette egyes iratainak kinyomtatását. Leonhard Lemmens kéziratát Girolamo Golubovich ellenőrizte, javította és készítette elő a nyomtatásra. Néhány hónap múlva, 1929-ben Lemmens meghalt. Golubovich, aki még néhány rövidítést eszközölt a müben és további információkkal egészítette ki azt, 1933-ban publikálta Lemmens kéziratát Collectanea Terrae Sanctae ex Archivo Hierosolymitano deprompta címmel. Ebben mindössze két oldal (244-245) foglalkozik a Szentföldi Kusztódia Levéltárának történetével.

Az a tény, hogy azóta a Szentföldi Kusztódia Történeti Levéltárának számos iratát közreadták, és publikálásuk egyre nagyobb méreteket ölt az utóbbi években, lehetôséget teremt arra, hogy elgondolkodjunk a levéltár történetével kapcsolatos kérdéseken, és számos hasznos új információhoz juthassunk a hiányzó láncszemek jobb megértéséhez. Most, hogy átfogóbban látjuk már a levéltár történetét, szeretnénk áttekinteni a levéltár létezésének mind a hét évszázadát, anélkül, hogy kiemelnénk valamelyik történelmi korszakot, helyzetet, szempontot stb.

Azt kell mondanom, hogy a levéltár történetének tanulmányozása és annak megismerése nem könnyű feladat, ahogy ezt korábban már többen megállapították, akik a Szentföldről írtak. Ez a legrégebbi levéltár, amely a Szentföldön létezik, dokumentumai pedig nemcsak a vallási intézményekhez tartozó helyek történetét örzik, hanem a katolikusok sokszázados jelenlétének történetét az egész Közel-Keleten. 
Minden levéltárnak megvan a maga története, s ez nem mindig ismert minden részletében. Az első iratok összegyüjtésének pillanatával kezdődően a levéltár létrehozásáig szükség van egy bizonyos időre; sok esetben ez hosszú időszak, s ezalatt nem hiányoznak olyan események sem, amelyek időnként közvetlenül veszélyeztetik a levéltár anyagának létét.

A levéltár története egy kicsit mindig azon intézmény kezdetének története is, amelynek részét képezi. Ez a történet ösrégi időkre nyúlhat vissza, éppen ezért hiányosságok is mutatkozhatnak a dokumentációban, mivel a levéltári gyüjteményről gondoskodni kell. Ha ezt nem teszik, akkor gyakorlatilag nem marad kutatható anyag azokból az időkből. Ilyen körülmények között a teljesség érdekében minden „tárgyat” dokumentálni és rendszerezni kell (ami egyébként egy levéltár esetében természetes dolog).

A levéltár „Nagy” története mellett létezik egy úgymond rejtett történet is. Egy intézmény levéltárának története nemcsak önmagában érdekes, de abból a tényből adódóan is - sőt, talán még inkább -, hogy közvetlenül vagy közvetetten, de bemutatja a mindennapi élet fejlödését is, amelyet nem mindig könnyű megérteni.

A levéltár története kissé specifikus, tudni kell - ahogy mondani szokás - a sorok között olvasni; de sosem szabad annak szerepét és jelentőségét kisebbíteni, nem szabad kevésbé fontosnak, kevésbé értékesnek, kevésbé valódinak tekinteni a történelem bemutatásának más formáihoz képest. A levéltáros számára a levéltár történetének ismerete kiemelkedő jelentőséggel bír tevékenységének kezdetétől a végéig.

A Szentföldi Kusztódia Levéltára valójában nem tartozik a nagy archívumok közé. Mindenekelött azt a katolikus intézményt mutatja be in partibus infidelium, amely évszázadokon keresztül képviselte az Apostoli Szentszéket ezen a területen. Érthető okokból egyaránt felkeltette a Hitterjesztési Kongregáció (Sacra Congregatio De Propaganda Fide), valamint Velence kormányának érdeklődését is.

Esetünkben olyan levéltárról van szó, amely nagyrészt a katolicizmus Szentföldre való visszatérését dokumentálja, ezáltal pedig segítséget nyújt abban, hogy megismerhessük a katolikusok jelenlétének történetét a Szentföldön és a szomszédos országokban. Ha a történész közvetlen bizonyítékokat szeretne találni az objektív tények dokumentálásához, meg kell találnia a megfelelö iratokat. Szentföldi Kusztódia Levéltárának jelentősége részint abból a tényből fakad, hogy a KözelKelet minden államát bemutatja, összegyüjti és mérlegeli mindegyik történelmét. Nem ritka, hogy valamely helyet vagy történelmi időszakot érintő írásos emléket találunk az anyagai között. Minden más katolikus szervezet, a maronita egyházzal együtt, legalább két évszázaddal a ferencesek után jelent meg a Szentföldön, és majdnem mindegyiket behatárolja az adott hely, a tevékenység módja, vagy a helyi hívekre vonatkozó joghatóság. A Szentföldi Kusztódia Levéltárának anyagát igen gazdagnak és minden közel-keleti misszió számára fontosnak ítélte Louis Bréhier író (BRÉHIER 1907, p. XII). A következőkben két kiváló történész álláspontját idézzük, akik elvitték a levéltár hírét a világba.

A XIX. század vége felé Golubovich - különösen a fermánok gyüjteményére vonatkozóan, mely akkoriban a Szentföldi Általános Prokuratúrán volt található - ezt írja:

„A szentföldi Kisebb Testvéreknek böséges a levéltára, és számos értékes, föleg arab irat található benne.” (GOLUBOVICH, 1898, p. XXVIII)

Ezután megerősíti véleményét: „a mi felmérhetetlen értékü Jeruzsálemi (Fermán)Levéltárunk” (uo. p. 125). Harminc évvel később ugyanaz a Golubovich még radikálisabb véleményt nyilvánít „a Szent Kusztódia nagyon gazdag Levéltáráról” (LEMMENS in GolUBOvich 1933, p. VII). Ez már a teljes levéltárra vonatkozik, kivételek és korlátozások nélkül, nem csak a fermánok gyüjteményére. 
Augustín Arce pontosabbnak tünik, amikor a levéltár jellemzésére a különféle iratok jelentőségét ismerteti. Csak a legfontosabb mondatait idézem:

„A levéltár egyik legértékesebb kincse az 58 pápai bulla és rendelet, melyeket eredetiben öriznek."

„A levéltár nagyon fontos részét képezik a fermánok.”

„Az új konventben (itt a San Salvatore ferences kolostorról van szó) nagy gonddal helyezték el gazdag sioni levéltárukat. [...] A mostani levéltárat több nemzedék levéltárosai gazdagították munkájukkal. Szinte folyamatosan érkeztek fontos iratok a levéltárba adományként, melyek különbözö módon és különbözö helyekről jutottak el oda: Madrid és Párizs kancelláriáiról, különbözö római kongregációkból, különösen a Hitterjesztési Kongregációból, a Rend miniszter generálisaitól, az ő római és madridi rezidenciáikról. Teljes és értékes iratok érkeztek Konstantinápolyból is."

„A Levéltár mindig nagyon jól gondozott és kiválóan rendezett volt. Ezt mutatja a katalógusok nagy száma, amelyek birtokunkban vannak és amelyeket ismerünk."

„A Levéltár gazdagsága föként a pápai dokumentumokban és a szultánok irataiban mutatkozik meg."(ARCE in PICCIRILlO 1983, pp. 140-142)

Golubovich és Arce véleményét tovább fogjuk vizsgálni a lehetőségek függvényében, azoknak a történelmi tényeknek és adatoknak az ismeretében, amelyek mindig hiteles dokumentáción alapulnak.

\section{Megnevezések}

A Szentföldi Kusztódia Központi Levéltára 1975-től viseli a Szentföldi Történeti Levéltár hivatalos nevet. Akkoriban fejezték be a San Salvatore kolostor bővítési és javítási munkálatait. Mindenekelőtt meg kell ismernünk a levéltár helyzetét az egyes történelmi korszakokban, valamint a dolgok akkori állapotát.

Az első írásos emlék a dokumentumok őrzéséről - abban az értelemben, hogy összegyüjtik azokat - 1467-1472 közé tehető. A Cenákulum melletti Sion-hegyi konventben összegyüjtötték a Capsa Privilegiorum néven ismert iratokat. Ezeket a gvárdián, vagyis a kusztos szobájában őrizték (vö. GolubOVICH 1898, p. 30; Diarium Terrae Sanctae 1962, p 17). A pápai bullák második említése, melyeket a Sacro Monte Syon-on in quadam parva capseta öriztek, egy későbbi időszakból származik (ld. KLIMAS in MAIARELli 2012a, pp. 77-118; 2012b, p. 43; vö. Codice A, 16. fol. ${ }^{1}$ ).

A XVI. század második felében Francesco Gonzaga miniszter generális említést tesz „Sion szent hegyének levéltárairól". ${ }^{2}$ Ennek az elnevezésnek nagy történelmi jelentősége van, mivel a Sion-hegyi kolostort a Cenákulummal együtt 1551-ben elveszítették (VERNIERO in GOLUBOVICH 1929, pp. 157159); ez az elnevezés azonban annyira találó volt, hogy a XX. század elejéig használták. Például Francesco Quaresmi mindig ezt használja, amikor azokat a különleges pápai bullákat publikálja, amelyek a XIII. század elejétől 1588-ig tartó időszakból származnak (vö. QUARESMI 1880, pp. 288331) $)^{3}$ Q Quaresminél a XVII. század első évtizedeiben a „Sion szent hegyének Levéltárára” való

\footnotetext{
A kódexben említés történik olyan pápai bullákról, melyek a Jeruzsálemi Levéltárban találhatók.

Ezzel a kifejezéssel először ott találkozunk, ahol a szerző az iratot illetően arról tájékoztat, hogy az „,extat in sacri montis Sion archivis" (GONZAGA 1587, p. 107).

Hangsúlyozzuk, hogy ez a mü 1616-1625 között keletkezett, de csak 1634-1639 között publikálták elöször.
} 
hivatkozás bizonyos mértékben kötelező, mert konkrét kapcsolódásokat szül. ${ }^{4}$ A másik példa Roberto Razzoli szentföldi kusztostól ered. A ferencesek Keleten c. könyvében számos, az „Archivio Sacri Montis Sion"-ban ${ }^{5}$ található iratra hivatkozik.

1564-ben már a San Salvatore kolostorban vagyunk, mivel a Sion-hegyi konventet 1551-ben elvesztették, a pápai dokumentumokkal, a keresztény uralkodók és a török hatalmak irataival együtt. Ezt már részletezés nélkül levéltárnak nevezik (vö. AVEIRO 1927, p. 177).

Aquilante Rocchetta , aki az 1589-1599-es években zarándokként tartózkodott a Szentföldön, egyes megfigyeléseinek alátámasztására ezt írja:

„Mindez azok közé az eredeti példányok közé tartozik, melyeket a Szent Sír bazilika Levéltárában őriznek." (RocCHETTA 1930, p. 393)

A „mindez” nem jelent különálló, másik levéltárat, hanem végig a Kusztódia központi levéltáráról van szó, mely sosem volt a Szent Sír bazilikában.

A XVI. század második felétől kezdik különféle neveken emlegetni, melyek mindig ugyanarra a levéltárra vonatkoznak. Itt felsorolom ezeket időrendi sorrendben, a teljesség igénye nélkül:

- Sion Szent Hegyének Levéltára (1587; a meghatározás nem túl pontos, de kitartott Quaresmi idejéig, 1616-1625-ig). ${ }^{6}$

- P. Pietro Verniero A Szentföld Krónikái vagy Annalesei c. összeállításában (első kiadás az 16341636-os években) hivatkozik „bizonyos török és arab nyelvü kéziratok”-ra „a San Salvatore kolostor levéltárából". Leltárának megnevezéseiben ugyanahhoz a terminológiához tér vissza:

„A Szentföld összes kéziratának jegyzéke és felosztása, melyek San Salvatore kolostorunk levéltárában találhatók.” (VERNIERO 1929, p. 102)

- Ugyanezzel a megnevezéssel találkozunk a XVIII. század első felében (pontosabban 1726-ban), amikor arról a helyről beszélünk, ,, ahol a Szentföld levéltára található ”7.

- A XIX. század végén és a XX. század elején visszatér egy ugyanilyen megnevezés, többek között P. Livarius Oliger müvében (vö. OLIGER 1925, p. 163). Ezt az eredeti gyüjteményt, mely valamikor a Sion-hegyi időkben létezett, később több alkalommal bővítették elrendezésének megváltoztatása nélkül, ezért nem őrizte meg eredeti formáját. ${ }^{8}$

- 1898-ból származik egy olyan megnevezés, mely a Jeruzsálemi Levéltárat a Titkárság Jeruzsálemi Levéltáraként határozza meg (GolubOVICH 1927, p. XXVII). A Diarium Terrae Sanctae időszakában, melyet Jeruzsálemben adtak ki 1908-1912 között, minden füzetben volt egy fejezet Ex Archivis Terrae Sanctae címmel. Ott ezekkel a kifejezésekkel találkozhatunk: Jeruzsálemi Levéltár; A Szentföld Jeruzsálemi Levéltára; A Szentföld Levéltára; A Szent

4 Elég csak két példát idézni. Gdański Bonawentura (1726-ban vagyunk) így ír beszámolójában: „Sion Szent Hegyének Levéltárát az 1726-os év szeptemberének 30. napján áthelyezték." Csak kis része (mennyiségi értelemben) származott „Sion hegyéről”. Mondanunk sem kell, hogy ez a mondat eredetileg kicsit másképp nézett ki: „A Szentföld Levéltárát az 1726-os évben áthelyezték” (vö. CASTELLANI in GOLUBOvich 1924, p. $\mathrm{X})$.

5 Vö. RAZzoLI 1909, p. 33 (fermánok); p. 42 (da Valenzano krónikái); p. 44 (fermánok); p. 49 (fermán); p. 53 (krónikák); p. 55 (fermán); pp. $58-59$ (4 idézet fermánokból); p. 66 (fermán); p. 115 (krónikák); p. 130 (Archivio de Sacro Monte Sion. Lettere ai Principi mss. 3); pp. 132-133 (3 idézet, Cronache mss. e Lettere ai Principi); p. 134 (krónikák); p. 138 (krónikák); p. 139 (kétszer, Regestum I); p. 142 (Relazione ms. Esistente nell'Archivio del Sacro Monte Sion); pp. 145, 147 (kétszer, krónikák); p. 148 (egyszer fermán, egyszer krónikák), p. 153 (háromszor krónikák).

6 F. Quaresmi esetében a XVII. század elején vagyunk. Sion Szent Hegyének Levéltárára hivatkozik (vö. QUARESMI 1881, p. 288).

7 Ld. 5. lábjegyzet, ahol Gdański Bonawenturát említjük.

8 A Szent Sír templom Levéltára (1598-1599-es évek), Szentföldi Levéltár (1726), az elnevezést L. Oliger használja 1925-ben. 
Kusztódia Levéltára; Sion Szent Hegyének Levéltára (vö. Diarium Terrae Sanctae 1909-1912, vol. 1., 117, 79; vol. 4., 107; vol. 1, 25, 44, 87, 210).

Lemmens Collectanea Terrae Sanctae ex Archivo Hierosolymitano deprompta címü munkájában gyakran használja a Kusztódia Levéltára vagy ennek változataként a Szentföldi Kusztódia Levéltára megnevezéseket (LEMMENS 1933, pp. 244, 283).

A terminológia sokszínűsége, mellyel ugyanazon tárgyat nevezik meg, arról tanúskodik, hogy nem mindig létezett világos meghatározás a Kusztódia Központi Levéltárára, mely végül a Szentföldi Kusztódia Történeti Levéltára nevet vette fel.

Ezt erősítik meg ugyanennek a levéltárnak a különböző megnevezései, melyeket időrendi sorrendben idézek:

- 1467-1472: Capsa Privilegiorum

- 1563-1564: Levéltár (fr. Pantaleone de Aveiro)

- 1598: A Szent Sír bazilika Levéltára (P. Aquilante Rochetta)

- 1616-1625: Sion Szent Hegyének Levéltára (Francesco Quaresmi)

- 1634-1636: A San Salvatore kolostor Levéltára (Pietro Verniero, valamint Francesco da Serino)

- 1637: A Szentföld Levéltára (Hitterjesztési Kongregáció, Leonhard Lemmens)

- 1672-1686: (a szent) San Salvatore kolostor jeruzsálemi Levéltára

- Sion Szent Hegyének Levéltára

- Jeruzsálemi Levéltár

- A Szentföld Levéltára (Juan de Calahorra)

- 1671-1674: Sacri Montis Sion archivia

- Archivium Sancti Salvatoris (P. Leonardo di Clore)

- 1726: Sion Szent Hegyének Levéltára

- A Szentföld Levéltára (általános jegyzék 1726-ból, Gdański Bonawentura)

- 1767: San Salvatore kolostorunk Levéltára (P. Giuseppe Antonio da Milano)

- 1850: A San Salvatore konvent jeruzsálemi Levéltára

- A San Salvatore kolostor jeruzsálemi Levéltára

- A San Salvatore konvent jeruzsálemi Levéltárai

- A Szentföld levéltárai

- A szentföldi konvent jeruzsálemi levéltárai (Eugenio Borré)

- 1898: A Titkárság jeruzsálemi levéltárai (Girolamo Golubovich, Serie Cronologica)

- 1909: Archivium Sacri Montis Sion (Roberto Razzoli)

- 1924: Archivia Conventus SS. mi Salvatoris (Status Descriptivus, 1924)

- 1933: Archivum Hierosolymitanum (Leonhard Lemmens, Girolamo Golubovich, Collectanea)

- 1975: A Szentföld Történeti Levéltára

1467-től 1933-ig tehát 26 megnevezés fordul elő: 6 alkalommal találkozunk a „Sion Szent Hegyének Levéltára” meghatározással (vagy hasonló meghatározásokkal); 9 alkalommal a „San Salvatore konvent Levéltárával” (vagy hasonló meghatározásokkal); 4 alkalommal a „Szentföld Levéltára” kifejezéssel; 2 alkalommal a „Jeruzsálemi Levéltár” megnevezéssel; valamint 5 olyan névvel, melyek csak egy-egy alkalommal fordulnak elő.

\section{Helyszín}

A fellelhető történelmi adatok, melyek a levéltári anyagok tárolásának körülményeiről szólnak, kisszámúak, töredékesek és majdnem mindig véletlenszerüek. Ez kétségkívül kissé megnehezíti témánk kutatását, mivel a Szentföldi Kusztódia Történeti Levéltárára vonatkozó egyes kérdések 
tisztázásához érdemes a megfelelő adatokat és tényeket felhasználni. Ha a dokumentáció bemutatása időrendi sorrendben történik, kiegészítő magyarázatok nélkül az egyes iratokat többé-kevésbé hibásan lehet érteni.

Levéltárunk mindig is Jeruzsálemben volt - a kezdetektől mindvégig: az első két évszázad (XIVXVI.) folyamán a Sion-hegyi kolostorban; majd 1560-tól a mai napig a San Salvatore kolostorban -, bár az idők során sokszor áthelyezték anyagát, ami megzavarta az állomány eredeti rendjét és egységét.

Az a legvalószínűbb, hogy az írásos dokumentáció tárolására leginkább használt hely a XV. század második feléig a kusztos szobája volt. Sajnos a tárolás helyére vonatkozó első világos utalást csak 1467-1472 között jegyezték fel, amikor Francesco da Piacenza kusztos így jelölte meg a jegyzék helyét:

„Nem szabad kivinni azokat a Gvárdián atya szobájából (cellájából), [...] és a privilégiumok szekrényében találhatók." 9

Szentföldi tartózkodása alatt, 1598-ban Rocchetta zarándok is megerősítette, milyen gondoskodással vették körül a testvérek levéltárukat a Cenákulum melletti kolostorukból való kényszerü távozásuk utáni első évtizedekben. Azokra a pápai dokumentumokra vonatkozóan, melyeket a kusztoshoz intéztek különböző alkalmak kapcsán, ezt írja:

„Mindent eredeti változatban öriznek a Szent Sír bazilika Levéltárában.”

(ROCCHETTA 1630, p. 393)

Rocchettának ez a tévedése arra utal, hogy lehetséges, hogy a levéltári anyag egy részét a XVI. század végén a Szent Sír bazilikában helyezték el, minden valószínüség szerint biztonsági okokból, de csak elég rövid időszakra.

1634-ben Paolo da Lodi szentföldi kusztos megerösíti, hogy

„San Salvatore kolostorunk egyes könyvei, pápai bullák és más kéziratok [...] valahol máshol vannak",

és utasítja Pietro Vernierót, hogy

„gyüjtse össze mindazokat a kéziratokat és hivatali könyveket, melyek a San Salvatore kolostor levéltárán kivül találhatók, majd rendszerezze azokat úgy, mint a krónikákat." (VERNIERO in GOLUBOVICH 1936, pp. 4-5).

Érdemes megérteni a XVII. század eleji helyzetet, amikor lehetséges, hogy a számunkra már ismert levéltárnak legalább egy részét a San Salvatore kolostor levéltárának nevezik (olyan néven, mely utal a levéltár helyére). Sajnos nem lehet semmilyen említést találni arról, hogy a levéltár a San Salvatore kolostorban található.

1655. október 15-én a Hitterjesztési Kongregáció ezt írja a kusztosnak:

„Utasítjuk, hogy a lakók [...] használják ennek a kolostornak (a San Salvatore) a hivatalos iratait. Más szobákat azonban engedjenek át a pénztár örzésére, és ezt a részt használják az archív kéziratok örzésére is, valamint kegytárgyak, berendezési tárgyak és más olyan dolgok örzésére is, melyek örzést igényelnek, helyezzék el ott $V$. R. aláirással, valamint a nélkülözhetetlen dokumentumokat is, melyeket évente ellenörizni kell." (LEMMENS in GOLUBOVICH 1921, p. 182)

9 „Non potetur extra Cameram patris Guardiani (Custodis) [...] et stet in capsa privilegiorum” (Diarium Terrae Sanctae 1909-1912, vol. 1., p. 17). 
A római rendelkezés nem mindig felel meg az igazságnak, amikor ,az archív iratok ôrzésére szolgáló szobák" kifejezést használja (ami a jeruzsálemi San Salvatore kolostorra vonatkozik), amennyiben nem tudunk más hasonló hivatkozásokról. Különösen érdekes azonban a dokumentum gondolatmenete, mely teljes tisztelettel ugyanolyan jelentőségünek tekinti a levéltárat, mint a kincstárat és az egyéb struktúrákat, melyek nélkülözhetetlenek egy kolostor müködéséhez.

Jobb példa ugyanennek a kongregációnak 1655. szeptember 15-én kelt irata:

„A legjelentösebb és legjobb dolgok közé - melyek nélkülözhetetlenek ezeknek a szentélyeknek megfelelö irányításához - tartoznak a dokumentumok és kéziratok, melyek védik azok érdekeit." (Uo. p. 181)

Egy 1681-es feljegyzés megemlíti ezt az iratot, és azt mondja, hogy ez a levéltárban vagy a pohárszékben található, mely a felsőbb elöljárók szobájában van Jeruzsálemben (vö. Atti Discretoriali. Reg. K/Ab, 230). ${ }^{10}$

A XX. században Antonio Cirelli egy 1682. május 8-i dokumentumban a következő kiegészítést olvassa:

„A jelen másolatot a Gvárdián Atya jeruzsálemi Levéltárában nyomtatták és találták meg Aposztázia - Arissa - Arabica - Örmények - Betlehem megjelölésekkel; a Harissza nevü rendházban találhatók az eredeti példányok, melyeket nagyrészt a jeruzsálemi San Salvatore kolostor titkárságán pecsételtek le." (CIRELLI 1918, p. 157) ${ }^{11}$

Ennek a levéltárnak az általános jegyzéke, melyet 1726-ban Gdański Bonawentura rendszerezett, ezekkel a szavakkal kezdődik:

„A Szentföld Levéltárát az 1726-os év szeptemberének 30. napján átvitték, hogy elhelyezzék egy szekrényben, mely annak a szobának ajtajával szemben található, ahol az elöljáró alszik. Az anyagot hét szekrényben helyezték el, amelyeket olyan zárakkal és kulcsokkal láttak el, melyeket a tetejükön egyforma mintával jelöltek meg." (CASTELLANI in GOLUBOVICH 1924, p. X)

Ez a rajz vázlatos formában mutatja meg a szekrény tartalmát és a helyet, ahol a szükséges dokumentumokat a tárolás helye szerint meg lehet találni. A szekrény egy része „az itt lévő listák tárolására” szolgál,

„melyek azon iratok témáját tartalmazzák, melyek ebben vagy abban a szekrényben vannak elhelyezve, s mely arra szolgál, hogy szükség esetén könnyebben meg lehessen találni azokat” (uo. p. XI),

más szóval azt az igényt jelzik, amit ma folyamatos levéltárnak nevezünk. Más híradások a levéltár őrzési helyére vonatkoznak. Gdański Bonawentura bemutatja a levéltár újrarendszerezésének vázlatát, melyet aztán ő maga valósított meg.

Úgy tünik, a levéltárat nem mindig őrizték példás rendben, bár többnyire megvolt a kijelölt és szervezett helye. 150 év múltán elkezdődött a Legszentebb Üdvözítőről nevezett új templom építése. Erről a helyzetről tájékoztat Eleazar Horn, aki az események idején élt (1724-1744 között tartózkodott

10 Megírták, hogy a dátum nélküli feljegyzés a jegyzékben található más dokumentumok között. Az egyik 1681. január 18-i, a másik 1681. október 10-i.

11 Cirelli, aki 1857-1859 között a Szentföld Annaleseit készítette, a kiegészítésben ezt írja: „Ha az atya, aki teljes precizitással irja le levéltárat, átveszi ennek a hétalvónak a magatartását és követni fogja a hanyagságban, vissza kell majd térnie, hogy megnézze a kolostort és az egész Szentföldi Kusztódiát. O! Quantum mutata ab illa." 
a Szentföldön), és aki megemlíti a kis könyvtárat, amely „a diskretor atyák celláiban (in cellis PP. Discretorum)" volt található, ahol a kusztos olasz-latin könyvei voltak. Ezt 1730-ban áthelyezték, „mivel a Szentföldi Levéltárat szolgálták [...] azt javasolta, hogy nevezzék így a Krónikák folytatását: Res Terrae Sanctae, Francisci Gesta Suaeque Achivum hoc, Sacrae Religionis habet (1726)." (HORN 1902, p. 208) ${ }^{12}$

A titkár és a jeruzsálemi gvárdián különleges gondoskodását bemutatva Horn így magyaráz:

„Hasonlóképpen, ha nincs más, egy különösen képzett pap krónikásként köteles szorgalmasan feljegyezni a szentföldi testvérek tetteit, az írásokat hüen örizni a levéltárban, elhelyezni azokat a megfelelö helyen, hogy a kartoték segítségével könnyebben meg lehessen azokat találni.",13

Meg kell jegyezni tehát, hogy kezdetben a levéltár rendszerezve volt, még levéltárost is kineveztek. A kusztódia levéltárosának pozíciója kis szünetekkel egészen 1918 végéig tart.

Chateaubriand 1806 októberében egy megjegyzést tesz. Rövid jeruzsálemi tartózkodása alatt észrevételezi, hogy a levéltárat nem jó helyen őrzik. Ezt írja ugyanis kitűnő Itinéraire de Paris à Jérusalem c. müvének lapjain:

„Az atya megengedte nekem, hogy megvizsgáljam a könyvtárat és a kolostori levéltárat. Sajnos a könyvtár és a levéltár az évszázadok alatt szétszóródott. [...] Egyes iratok megsemmisültek, különösen a fermánok."14

A XIX. század folyamán a levéltár történeti része jelentősen veszít formájából, mivel rendszerezés nélkül a titkárságon hagyták és nem tárolták mindig megfelelően. Ezért jelenleg nincs birtokunkban a teljes dokumentáció, bár ami megmaradt, az is elég jelentős.

Hogy V. Márton pápa bulláját idézhesse, Eugenio Bore írt a San Salvatore kolostor titkárságára, keresve az említett dokumentumot. A pápai bullákra vonatkozóan IX. Gergelytől IX. Piuszig hivatkozásokat szeretett volna találni a San Salvatore kolostor Jeruzsálemi Levéltárában (BORE 1935, p. VII). ${ }^{15}$

A levéltár és a könyvtár összekeverése így jelenik meg Jacques Mislinnél:

\section{„A kolostori levéltárban ezernyi irat található [...]. Könyvtáruk 900 fermánt tartalmaz." 16}

Cirelli, aki 1846-ban a Szentföld kijelölt krónikása volt, elismeri a történelmi munkákat illetően, hogy

„nem tudom azokat saját használatomra a levéltárban tartani, mert helyhiány miatt a titkárságon vannak, ahonnan mindig P. Clemente Solero [...] titkár

12 Említés titkári érdemeiröl: ld. HoRN 1902, p. 153.

13 „Item si non sit alius Sacerdos particulariter insitutus Chronologus, debet res gestas Fratrum Terrae Sanctae diligenter adnotare, in Archivo scripturas fideliter servare, juxta ordinem eosdem proprio suo loco distribuere, ut cum registro facilius inveniantur" (uo. p. 236).

14 „Les Pères m'avaient permis d'examiner la bibliothèque et les archives de leur couvent. Malheureusement ces archives et cette bibliothèque furent dispersées il $\mathrm{y}$ a près d'un siècle [...]. Quelques papiers échappèrent à la dévastation, en particulier les firmans [...]" (CHATEAUBRIAND 1871, p. 270). Nem különbözteti meg a könyvtárat és a levéltárat, nem ismeri a köztük lévő alapvető különbséget. Vajon ez csak hiba, vagy apró figyelmetlenség, ami a sietős következtetéseken alapul? Pillanatnyi tévedés, vagy a későbbiekben is megmaradt? Vajon a könyvtár és a levéltár összekeverése véletlen dolog?

15 Fermánjairól ld. másik cikkemet, melyet a Jeruzsálemi Levéltár e részének szenteltem.

16 „Dans les archives du couvent, il y a des milliers de documents [...]. Leur bibliothèque possède aussi neuf cents firmans" (Mislin 1876, pp. 586-587). 
jóindulatára kell hagyatkoznunk [...], aki valóban sok idöt tölt el a nekem szükséges iratok keresésével a régi kartonok között, hogy megszerezze, amit kérek tőle." (CIRELLI 1918, pp. 353-354; vö. Registro delle Congregazioni dal 1846 al 1855 [ms.], 1)

Carlo Guarmani 1745. június 14-én Desidero Casabarscianóhoz intézett levelében arról ír, hogy saját másolatot készít „a San Salvatore kolostor Titkárságának Levéltára” jegyzékéről. Néhány 1766 elötti dokumentumra hivatkozva megerősíti, hogy azokat „még a San Salvatore kolostor Titkárságának Levéltárában őrzik”. Egy 1514-ből származó irat publikációjában megjegyzi, hogy

„a másolat az eredetiről készült, mely a San Salvatore kolostor Titkárságának

Levéltárában található.” (GUARMANI 1872, pp. 281-282, 284, 381)

Ezekhez a XIX. századból származó adatokhoz hozzátehetünk még egyet, melyben Golubovich a régi levéltári jegyzék leírását idézi, melyet müve elején helyez el, ezt írva róla: „gondosan őrzik a Titkárság Jeruzsálemi Levéltárában”( GoluBOVICH 1898, p. XXVII, 1. jegyzet).

A Szentföldi Kusztódia sok évszázados történetét nézve jellemző, hogy amikor számba vették azokat az intézményeket, amelyek valamikor a San Salvatore kolostorban müködtek (szeminárium vagy teológiai iskola, könyvtár, infirmárium és más különböző, ettől a konventtől függő intézmények), soha nem említették a levéltár sok évszázados létezését (vö. uo. pp. 194-197). ${ }^{17}$

Felmerül a kérdés, a San Salvatore kolostor mely részében őrizték az elmúlt évszázadokban a Szentföldi Kusztódia Történeti Levéltárát. Tudjuk, hogy a XVII. század első hatvan évében a kusztos szobájában rendszerezték és őrizték a levéltárat. Valamivel később, a XIX. században a titkárság volt ennek a helye.

Sajnos ma már gyakorlatilag lehetetlen pontosan meghatározni azt a helyet, ahol a kusztos szobája és a titkárság volt, egyszerú okból: a San Salvatore kolostort 1882-1885 között helyreállították és átépítették. A rendház nagy része teljesen megváltozott. A rendház elrendezését, amelyet Horn a XVIII. század első felében feljegyzett, jelenleg már nem lehet rekonstruálni (ld. HoRN 1902, p. 189).

Az új templom építésének idején és kicsit később a kolostort átépítették és meghosszabbították a Felsőváros falainak mentén, keleti irányba. Ez a rész eleinte a nagy refektórium fölött volt található. Ennek keleti részében helyezték el az új, háromszobás titkárságot, egy szobát pedig a levéltár számára jelöltek ki. Erre a célra három nagy szekrényt vásároltak, amelyek beborították a falakat, de hagytak szabad helyet a bejárat közelében. A levéltárnak ez a rendje érintetlenül marad 1974-1975 teléig.

A Kusztódia levéltárainak évszázados történetét bemutató összefoglaló elemzésében Golubovich ezt írja:

„Levéltárainknak ezen szerencsétlen változásai és történései, amikor még a Szentföld elöljárói sem tudták megörizni a legértékesebb maradványokat, nemcsak az idő károsító hatása és a drámai események miatt következtek be, hanem az elöre nem látható és dühödt pusztítások miatt is, melyek Keleten megszokottak.”

Megmentési módként ebben a helyzetben azt ajánlja, kérjenek segítséget Európától, melynek kötelessége, hogy „megörizze a teljes történetét mindannak, ami a megmaradt dokumentumokban találhatô" (GolubOVICH 1898, p. XIX).

Lehetséges, hogy ezek után a jelentések után állítottak be a levéltárba egy fémszekrényt, amelyben a pápai bullákat őrizték, s amelynek jobb oldalára nagybetükkel az volt írva:

17 Valóban érdekes látásmód, egyáltalán nem tesz említést a kolostor melletti plébánia esetleges létezésérôl. 
„Bullarium Terrae Sanctae in hoc armario incombustibili disposuere/notis adiectis",

a bal oldalára pedig:

„Anno 1907/Secretarius N. Rosati et officialis Curiae A. Gassi iussu/Rmi P. Roberti Razzoli Custodis benemerentissimi”.

Ez inkább mutatós, mint hatékony megoldás volt.

Az idő múlásával azonban igény támadt arra, hogy radikálisabban oldják meg a régi problémát. A Kusztódia vezetősége 1915. január 3-án elhatározta, hogy

„alkalmas helyet készít a Kusztódia Levéltárának, ahol a Prokuratúra által elzárandó fermánokat és más iratokat, szerzödéseket, igazolásokat stb. fognak örizni” (Atti Discretoriali. Reg. K/R, 107).

Az 1918. augusztus 12. és 21. között készült rendszerező leírásban helyet kap többek között az összes fermán és minden, a szentélyeket érintő dokumentum, amelyeket a titkársággal szembeni levéltárban őriztek. 1918. december 30-án ugyanazt a problémát ismertetik: elhatározzák, hogy minden, a Szentföld tulajdonaira vonatkozó iratot összegyüjtenek a Kusztódia Levéltárában a fermánokkal és a szentélyekre vonatkozó iratokkal együtt (uo. p. 221), de a fermánok gyüjteményét nem sokkal ez után a döntés után mégis a titkársággal szemben lévő szobákban helyezték el két nagy szekrényben, ahol egészen 1961 végéig maradtak. Úgy tünik tehát, hogy a probléma nagy része nem oldódott meg, és az ezt követő negyven év alatt sem találtak megoldást erre a sokoldalú problémára. 1960. május 16-án

„született meg a döntés, hogy a Kusztódia San Salvatore kolostorban lévó Levéltárát és könyvtárát, a konvent fennállásának 400. évfordulója alkalmából új helyre költöztetik" (Acta Custodiae Terrae Sanctae 1960, 5: 100).

Mindig is szoros összefüggést tapasztaltunk a levéltár és a titkárság között, és csakis az új megközelítés tette lehetővé a levéltár újrarendszerezését. Ezeket a megoldásokat kompetens személyek javasolták, éspedig nagyon konkrétan, ahogy ezt az új hivatalos krónika feljegyzi, amely a titkárság új székhelyének felavatása alkalmából íródott, ahol megemlítik azokat a személyeket is, akik közvetlenül érdeklődtek a levéltár iránt.

„Az évek múltán világossá vált annak tarthatatlansága és kényelmetlen volta, hogy ugyanott helyezték el a Kusztódia Történeti Levéltárát és a Titkárságot. Ezt Sabino Gallego vizitátor generális hangsúlyozta 1959-es vizitációja alkalmával, amikor is utasítást adott, hogy találjanak megoldást erre a komoly problémára. Nagyon alkalmas idö ennek megvalósitására a jeruzsálemi San Salvatore kolostor 400 éves fennállásának ünneplése." (Acta Custodiae Terrae Sanctae 1959, 4: 104)

Végül úgy döntöttek, hogy 1960. május 16-án ünneplik meg, hogy új székhelyet létesítettek a könyvtárnak és a kusztódia levéltárának. Mindig is problémát jelentett, hogy nehéz a könyvtár szükségleteinek megfelelő helyiséget találni, de a levéltár új helyére vonatkozó ötlet elég gyorsan megvalósult. Hosszú egyeztetés után a régi titkárság és levéltár helyén helyezték el, amely ezentúl már csak ez utóbbi rendelkezésére állt. A három nagy szoba elegendő volt a levéltár minden anyagának, melyet a kusztódia új levéltárosa, Metodio Brlek rendszerezett.

Ezzel együtt azonban új helyet kellett találni a titkárságnak. Volt négy szük és sötét kis szoba, a régi titkársággal és levéltárral szemben, melynek ablakai a templom harangjaira néztek. Ez a négy szobácska a Kusztódia könyvlerakatául szolgált. Miközben helyiségeket átalakították az új titkárság 
szükségleteinek megfelelően, a fermánok őrzésére szolgáló szekrényeket tönkretették. A levéltár és a könyvtár új helyiségeinek átalakítási munkálatai 1961 szeptemberében fejeződtek be. A helyiségeket 1962. május 21-én este nyitotta meg ünnepélyesen Carl Talloric, a Szentföld általános vizitátora (vö. La nuova Segreteria di Terra Santa 1962, 99-100).

Itt említem meg az utolsó dátumot, 1962. május 21-ét, amelyet hivatalosan is úgy lehet tekinteni, mint a Szentföldi Kusztódia sok száz éve létező Történeti Levéltára önálló létének kezdetét. Ekkor használták ugyanis elöször hivatalosan ezt a megnevezést. A volt titkársági levéltár két egybenyitott helyiséget örökölt.

Maurilio Sacchi szentföldi kusztos idején (1974-1980) elvégezték a levéltár helyiségeinek feltétlenül szükséges felújítását, valamint új, speciális fémszekrényeket vásároltak. ${ }^{18} \mathrm{~A}$ többi felújításra - mely nélkülözhetetlen volt a szentföldi és a ciprusi kolostorok számos dokumentumértékü archív anyagának tárolásához -, valamint a kutatásokra és a kéziratok Jeruzsálembe vitelére 19982002 között került sor Narcyz Klimas levéltáros irányításával. ${ }^{19}$

2003. január 10-én Giovanni Battistelli szentföldi kusztos levelet írt a Kusztódia helyi elöljáróinak (I.sz. 0013/04), amelyben azt kérte tỏlük, hogy a házak történelmi levéltárait szállítsák át Jeruzsálembe, a Kusztódia Történeti Levéltárába. A munka megvalósításával Narcyz Klimas kusztódiai levéltárost bízta meg.

Mindez a szentföldi házakat, valamint Ciprust, Rodoszt, Szíriát, Libanont és Itáliát illetően 2003mal kezdődően zajlott le. Itália, Ciprus és Rodosz esetében a dokumentumok összegyüjtése és vizsgálata még 2005-ben is tartott. A rodoszi anyag végül nem került Jeruzsálembe, hanem a Santa Maria delle Grazie rendházban újonnan kialakított részben nyert elhelyezést, a Narcyz Klimas által kialakított rend szerint.

Libanonban a dokumentumokat a bejrúti Szent József rendházba vitték, Szíriában pedig az aleppói Szent Ferenc rendházba. Mindkét esetben leltár készült az anyagokról. A libanoni anyag nem túl terjedelmes és aránylag új, a 19. századtól kezdődik, kivéve Harisszát, ahol volt néhány régebbi dokumentum is a 17. századtól. Aleppóban a levéltár kisméretü, de jól dokumentált, több tulajdonjogi dokumentummal a 17. századtól fogva. Plébániai okmányok és jegyzékek is találhatók ugyanettől az időtől kezdve, valamint a térség lelkipásztori életére vonatkozó egyéb dokumentumok, például az örményekről, amiről napjainkban élénk vita folyik. Még Egyiptomban kell majd elvégezni ezt a munkát, főleg Kairóban a Muski rendházban, de ez egy külön nagy müvelet, hiszen nagyon sok és fontos dokumentumot őriznek ott.

2008-ban kezdődött meg a bullák és a fermánok fondjának digitalizációja, és 2009-ben be is fejeződött. ${ }^{20} 2009$-ben kezdődött az együttmüködésünk Andrea Maiarelli professzorral a jeruzsálemi levéltár átrendezése és leltározása kapcsán. Az átrendezés az ún. „nyugati” anyagra korlátozódott, tehát nem érintette a „keletit”, amely a fermánok fondját jelenti. Ennek oka a nyelvi nehézség volt (török nyelvű szövegek arab írással).

2010-ben kezdtük meg az átrendezés és új katalogizálás munkáját Tiziana Nandesi, Valeria Vestrelli és Maria Cominacini kutatókkal. A munka 2011. május végén zárult le, de mivel közben folyamatosan érkeztek anyagok a régi kusztódiai prokuratúráról, a titkárságról, valamint más rendházakból, ahol a 2003-2004 között Jeruzsálembe hozott anyagokon kívül elökerültek egyéb

18 A levéltár felújításának, bebútorozásának és elrendezésének munkálatairól ld. A Kusztódia Káptalanjainak Beszámolója 1962-től 1988-ig, melyet M. Brlek, a Kusztódia levéltárosa írt (saját kezűleg).

19 A Jeruzsálembe került iratok listájáról ld. ugyanennek a levéltárosnak a Beszámolóját (előkészületben).

20 Néhány eredménye látható a Kusztódia hivatalos honlapján (www.custodia.org) és a következő linken: http://www.jewishhistory.com/FRANSISCANS/ 
dokumentumok is. A Kusztódia történelmi levéltáraiban őrzött hatalmas anyag analitikus és tudományos katalogizálása a legmodernebb módszerekkel és a hatályos eljárási kritériumokkal történt.

2013. február 28-án a Kusztódia központi vezetőségének székhelyén, a San Salvatore kolostorban átadták a Szentföldi Kusztódia Történeti Levéltárának új székhelyét. Ugyanitt bemutattuk a levéltár katalógus-leltárát, amelyet három hatalmas kötetben jelentettünk meg: ANDREA MAIARELLI (ed.) (2012): L'Archivio Storico della Custodia di Terra Santa (1230-1970). Biblioteca Bio-Bibliografica della Terra Santa e dell'Oriente Francescano, Quinta Serie - Sussidi 30-31-32, Edizioni Terra Santa, Milano.

I. kötet: NARCYZ KLIMAS: Introduzioni. pp. 245+168;

II. kötet: Inventario dell'Archivio della Curia custodiale. pp. 1-738;

III. kötet: Inventari degli archivi aggregati all'Archivio della Curia custodiale, delle case religiose, delle parrocchie, delle viceprocure, delle case di formazione, delle case nove e appendici. pp. 739-1231.

Ehhez a publikációhoz kapcsolódott egy év múlva egy másik, amely az átrendezés és az új székhelyre költözés idejéig tekinti át a levéltár történetét: NARCYZ STANISŁAW KLIMAS (2013): La Storia dell'Archivio Storico della Custodia di Terra Santa. Biblioteca Bio-Bibliografica della Terra Santa e dell'Oriente Francescano, Quinta Serie - Sussidi IV., Edizioni Terra Santa, Milano.

A Szentföldi Kusztódia Történeti Levéltárának új székhelyén rendelkezésre állnak a megfelelő terek, ahol a tudósok vizsgálhatják a dokumentumokat, olvasóterem, levéltárosi hivatali helyiségek, mühelyek még a nagyobb formátumú dokumentumok tanulmányozásához is. Görgős polcokon modern elhelyezést nyertek az egyes részek: bullák, fermánok, történelmi és földrajzi térképek, ingatlanok helyszínrajzai, építési tervek és egyéb fondok.

\section{Hiányok és okaik}

Eltủnések, lopások, kisebb vagy nagyobb rongálások és a dokumentumok különböző okokból történő szokásos megsemmisülése majdnem minden levéltár történetének részét képezik. Nagyon hasznos lehet, ha a levéltár történetének erről a részéről is tudunk, kiváltképp akkor, amikor jobban meg kell magyarázni egy-egy múltbeli dolgot, melyet nem lehet más módon megvilágítani. Elég tehát, ha különös figyelmet fordítunk egy-egy olyan esetre, amely jellemző a mi levéltárunkra.

Mind a mai napig gyakran szóba kerül az a rendezetlenség, amely hosszabb ideig fennállt, s ami nem kedvezett a levéltár gyarapodásának. Meg kell említeni azonban néhány konkrét esetet is, amikor kisebb vagy nagyobb mértékben szegényebb lett a levéltár.

Alessandro Mombelli 80 évvel ezelött ezt írta:

„A San Salvatore kolostor Levéltárának megsemmisülése tüzvész miatt [...] nem lehetséges [...]"(MOMBELLI 1934, p. 71),

vagyis teljességgel tagadja ennek lehetőségét. Nagyon elhamarkodott ez az állítás, kényelmes és nagyon egyszerü, mert nem képes megmagyarázni a dokumentáció körüli problémát, és a végén nem ad semmiféle magyarázatot. A Szentföldi Kusztódia Levéltára Golubovich szerint nagyon gazdag, és valóban, még gazdagabb lehetne, ha nem lettek volna tüzesetek, bebörtönzések és más külső okok, 
melyek pusztítást okoztak a levéltárban; de gazdagabb lehetne akkor is, ha kicsit több gondossággal kezelték volna ezeket az iratokat a Szentföldi Kusztódia szerzetesei. ${ }^{21}$

Amikor Lemmens külön megemlíti azt a rossz hírt, hogy a levéltárból eltünt a Sion-hegyről származó összes kézirat, melyeket a testvérek 1537-1540 között összegyüjtöttek, (ahogy erről a krónikás beszámol), megjegyzi:

„A levéltár megsemmisítéséröl vagy kirablásáról szóló véleményt nagyon gyakran ismétlik a szerzők [...]. De kétséget ébreszthet az, hogy a szerzők már abban az időben sem megegyezöen irtak erröl, amikor a fosztogatás tettesének megnevezéséröl van szó; sokkal inkább kétségessé teszi ezt a bizonyos rablást az a tény, hogy a Kusztódia levéltárából egyáltalán nem hiányoznak az az elött a bizonyos 1537-es év elött kiadott iratok." ${ }^{22}$

Lemmens itt utal az iratok rövid jegyzékére, mely még 1537 előttről származik, s melyet akkor még öriztek az említett levéltárban (vö. uo. pp. 244-245). Lemmensnek erre az állítására Golubovichnak megvan a maga ellenvéleménye:

„Mégis, még ha ez a kevés XIV-XV. századi irat el is kerülte a megsemmisülést és mostanáig megmaradtak a jeruzsálemi levéltárban, nem lenne hasznos kétséget ébreszteni afelöl vagy tagadni, hogy a XIII-XIV. századi iratok többsége, mi több, túlnyomó többsége megsemmisült rablás, járvány vagy tüzeset következtében, vagy más szerencsétlen események miatt mind Jeruzsálemben, mind a Szentföld többi kolostorában." ${ }^{23}$

Nagyon nehéz erről a témáról vitát folytatni, mert nem tudjuk, milyen alapon ismerjük el valamelyik kiváló történész igazát. Jobb, ha csak a konkrét adatokat és írásos emlékeket idézzük a XIV. századtól kezdve napjainkig, melyek - természetesen anélkül, hogy kizárnánk a megsemmisülés és eltűnés lehetőségét arról a helyről, melyet a Szentföldi Kusztódia Történeti Levéltárának nevezünk - történelmi információt hordoznak a minket érdeklő témáról, és még ha negatívan mutatják is meg az említett levéltár történetének egy részét, egyidejűleg mégis lehetőséget nyújtanak arra, hogy objektívan mutassuk be a valós helyzetet.

A Szentföldi Kusztódia első konstitúciója, mely 1377-ben jelent meg, a 6. cikkelyben így rendelkezik:

21 Meg kell nézni pl. a következőt: „Lugendum sacre thesaurum Archivi (Conventus S. Salvatoris) non attius se protender quam saec. XVII, infauste enim temporum, incendia, carceres conjuvarunt contra antiquiora monumenta quae vel incendio deleta, vel dispersa vel ammissa sunt” ( „Fájlalnunk kell, hogy a szent Levéltár kincse [a San Salvatore kolostoré] nem terjed ki korábbi [idöszakra], mint a XVII. század, mert az idö, a tüzesetek, a bebörtönzések a legrégibb iratok ellen dolgoztak, melyek tüzben semmisültek meg, szétszóródtak vagy elvesztek")(Status Descriptivus Custodiae Terrae Sanctae anno Domini MCMXXII iussu et auctoritate Rev.mi P. Ferdinandus Diotallevi totius Terrae Sanctae Custodis digestus 1924, p. 3;vö. LEMMENS 1933, p. 245).

22 „Sententia tali de archivi destruzione vel expoliatione saepissime ab auctoribus repetita invenitur [...]. Sed jam dissensus scriptorum in tempore et in auctoribus depraedationis indicandis dubium ingerere potest; multo magis illam depraedationem dubiam facit factum, quod minime desunt in archivio Custodiae documenta ante illum 1537 emanata” (LEMMENS 1933, p. 244). A krónikás, P. Verniero elbeszéléséröl ld. P. VERNIERO 1929.

23 „Verumtamen etsi haec tam pauca documenta saec. XIV et XV ab interitu vindicata fuere, et in archivio Hierosolymitano adhuc supersunt; non inde fas erit in dubius vertere vel negare, quod major innuo maxima pars monumentorum, a saec. XIII usque in finem saec. XVI, vel depraedatione, vel peste, vel igne consumpta, vel quoris alio nefasta casu perierit tum Hierosolymis, tum in caeteris Coenobiis Terrae Sanctae" (LEMMENS 1933, p. 245, 1. jegyzet). 


\begin{abstract}
„A Regula szorosabb betartása végett, és hogy megmutassák, hogy kerülik a pénzt, a Testvérek ne követeljenek az emlitett személyektöl (a Testvérek szolgálatában álló világi intézőktöl) beszámolót az alamizsnáról, se elszámolást; ne jegyezzék fel, milyen alamizsnát kapnak, ne írják be rubrikákba, milyen [összegeket] vesznek ki ebböl.,"24
\end{abstract}

Nehéz ezt lelki okokkal magyarázni, de gondolni kell arra, hogy a szentföldi ferences testvérek nem saját missziót vezettek, hanem az egész katolikus egyház nevében léptek fel. Ezért ha úgy is tủnik, hogy ezeknek a könyveknek - adminisztrációs jegyzékeknek és tulajdonjogi iratoknak - csak kifejezetten számukra van könyvelési dokumentum-értékük, tudnunk kell, hogy történeti dokumentum-értékük is van, mivel szélesebb körü a jelentőségük, mint első látásra gondolnánk. Az azonban tény, hogy az 1377-es elöírást túl aprólékosan tartották be, még annál is aprólékosabban, amint azt az adminisztrációs rendelkezés parancsolta.

A külső negatív tényezők között meg kell említeni a törökök XVI. századi (1537) győzelmét a keresztény hatalmak egyesített hadserege fölött, aminek következménye volt többek között a testvérek bebörtönzése is. A török hatalom a büntetés meglepö és váratlan módját szabta ki a testvérekre: át kellett adniuk szent helyeik kulcsait az örményeknek, arra kérve öket, hogy ideiglenesen gondoskodjanak a Kusztódiáról. Amikor a testvérek 38 hónap börtön után végre kiszabadultak, azt vették észre, hogy sok dolog eltünt, köztük számos kézirat is (ld. VERNIERO 1929, pp. 141-144). ${ }^{25}$ Ehhez hozzá kell tenni, hogy a testvérek majdnem nyolc éven keresztül laktak az ún. Kemencetoronyban a Cenákulum mellett (1551-1559 között), ami egyáltalán nem tette lehetővé a levéltári anyag megfelelő tárolását a hely szűkössége és alkalmatlansága miatt (vö. uo. pp. 165, 184).

A XVI. század második felében Francesco Gonzaga miniszter generális, aki történelmi szempontból akarta bemutatni a Szentföldi Kusztódiát, felpanaszolta a neki felajánlott iratok nagy hiányosságait. Íme a szavai:

„Kétségkívül nagyon sok példát hozhatnánk fel itt a Szentföld helyeiröl, melyen
a mindenkinél jobb és fölségesebb Isten egyedïl az ö végtelen irgalmasságából
és szeretetéböl, teljes érdemtelenségünk ellenére véghez kivánta vinni az
emberiség megváltását, ha azoknak a testvéreinknek, akik eljutottak a
törökökhöz, gyakoribb kapcsolatuk lett volna velük, és ha tovább tartózkodtak
volna ezeken a helyeken. A testvérek ezekböl a nehézségekböl [eredö]
gondatlanságának és nagy hanyagságának köszönhetöen azonban-mivel nekik
a figyelemreméltó dolgok elkerülése a vallásuk - arra kényszerü̈lünk, hogy
hallgatva menjünk el ezek mellett a nagyon is figyelmet érdemlö [események]
mellett, mivel hiányoznak a régiek hü és biztos feljegyzései és dokumentumai." ${ }^{26}$

Egyes későbbi kutatók és a Szentföld témájával foglalkozó írók ugyanerre a következtetésre jutottak. Előszeretettel egészítették ki a hiányokat saját szavaikkal, mint pl. Francesco Quaresmi.

24

„Pro strictiore Regulae observantia et manifestatione pecuniae fuga, a predictis (amministratori secolari a servizio dei Frati) Fratres eleemosynarum rationem sive computum non exigant; quas recipiunt eleemosynas non scribant; quas distrahunt, in tabulas non redigeant" (GOLUBOVICH 1910, p. 218).

25 Ugyanebben a könyvben a 111. oldalon a krónikás ezzel az eseménnyel kapcsolatban elmagyarázza, miért „veszett el számos kézirat".

26 „Plurima haud dubio de loci Terrae Sanctae, in qua Deus optimus maximus pro sua tantum infinita misericordia atque miseratione, nullis peritus nostris meritis id exigentibus, humanam salutem operari dignatus est, in medium afferre possemus, si fratribus nostris ea petentibus frequentior cum Turcis consuetudo esset, sique longiorem in illis moram traherent. Sed ea est etiam, ab his difficultatibus, fratrum incuria, atque supina negligentia, quibus rerum notabilium praetermissio religio est, ut deficientibus nobis tum seniorum fideli, indubiaque traditione, tum quoque monumentis, ea silentio praeterire cogamur quae notatu dignissima sunt" (GONZAGA 1587, p. 106). 
Quaresmi, aki a XVII. században a Kusztódia elöljárója volt, bemutatja a levéltáron belüli pusztulást, csaknem Szent Ferenc idejétől kezdve. Az egykor a Szentföldön élő, sokak által ismert jó ferences testvérek emlékezetét ugyanis nem mindig őrizték meg. Ehhez hozzáteszi:

„És ennek valódi okait a legfényesebb és legtiszteletreméltóbb Francesco Gonzaga, a Szeráfi Rend egykori Miniszter Generálisa, később mantuai püspök [...] tárja fel, aki így beszél a kusztódiáról és a Szentföld helyeiröl."

Majd hozzáteszi ezeket a szavakat:

„Azért, hogy tudni lehessen, hogy az igazság az, amit közöltünk: amiket már elmondtunk, és amiket valahol máshol kell elmondanunk." 27

Ehhez az érveléshez Quaresmi nagyszerủ művének II. kötetében is visszatér:

„Úgy gondolom, bizonyára senki nem kételkedhet abban, hogy azokban az idöben, amikor a kisebb testvérek a Szent Városban laktak, akár Sion szent hegyén a szent Cenákulumban, akár a San Salvatore kolostorban, sokat szenvedtek a hitetlenektöl, és [tartózkodási] helyükön nem kevés emlékezésre méltó dolog történt velük. Akár hanyagságból, akár mert gyakran cserélödtek a testvérek, ezek nincsenek írásba foglalva, és mivel nem ismerjük eléggé körülményeiket, nem vettük bele öket ebbe az írásmübe; nem hagyjuk ki belöle azonban azokat a dolgokat, melyekröl vannak bizonyos értesüléseink, és amelyek ugyanott történtek a mi időnkben, és amíg ezen a vidéken vagyok. ${ }^{28}$

Pietro Vernierót 1634. január 8-án nevezte ki a Szentföld évkönyveinek megírására Paolo da Lodi szentföldi kusztos. Fáradozása gyümölcsének tiszteletreméltó és ismeretlen olvasóihoz ezt írja ajánlásában:

„Ne csodálkozz, hogy ezek az Annalesek nem tartalmazzák minden gvárdián nevét, akik régebben a Szentföldön kormányoztak, és még annak a kevésnek is, szégyenszemre, nincs megnevezve hazája vagy rendtartománya. [...] Sok eröfeszítést tettem, hogy a lehetö legpontosabban beszámoljak mindegyikükröl, de sajnos nem volt lehetséges az ösi kéziratok hiánya miatt, mivel a testvérek nem gondoskodtak megfelelö emlékekröl, nem írtak könyvet arról, mikor kezdték és mikor fejezték be kormányzásukat az egyes gvárdiánok (rövid idö múlva elkezdték ezt), és az a kevés név, melyeket nagy fáradsággal megtaláltam a föleg arab és török nyelvü kéziratokban, melyeket egyes házak és mezök megvásárlása okán állítottak ki a különbözö gvárdiánok [...], ezek a kéziratok félig megsemmisültek, különösen az arab nyelvüek.”(VERNIERO 1936, pp. 7-8)

Később idézi a kusztosok listáját, folyamatosan ezt ismételve:

27 „Et rationes huius rei veras adducit illustrissimus et reverendissimus sanctae memoriae P. F. Franciscus Gonzaga, aliu seraphici ordinis minister generalis, et postea Mantuanus episcopus [...] loquens de custodia et locis Terrae Sanctae, in hunc modum.” Majd hozzáteszi ezeket a szavakat: „,Verum quae indicavimus ita esse, tum ex dictis, tum ex dicendis alias, velut ex usque leo, dignoscetur" (QUARESMI 1880, p. 123).

28 „Interea temporis, quo Minores fratres in sancta civitate, vel in sancto coenaculo sacri montis Sion, vel in conventu sancti Salvatoris habitaverunt, multa eos passos fuisse ab infidelibus, et in eorum locis non pauca memoria digna accidisse, neminem credo merito dubitare posse, etsi vel incuria, vel frequenti mutatione fratrum, litteris consignata non fuerint, atque ideo, quia non sat certo de eorum circum stantiis nobis constat, nostro huic operi non inseuerimus; ea tamen quorum certam notitiam habemus, et quae nostro tempore, et dum in istis partibus existerem ibidem acciderunt, non pretermittemus"(QUARESMI 1881, p. 43a). 
„Még nagy eröfeszités árán sem tudtam teljes és világos tájékoztatást találni mindegyikükröl, mivel a testvérek a kezdet kezdetétöl nem gondoskodtak arról, hogy legyen információ az első atyákról, ezért vannak ilyen nagy hiányosságaink.”(VERNIERO 1929, p. 2)

Ezután még hozzáteszi:

„Az említett kéziratok és kormányzati könyvek a San Salvatore kolostor levéltárában vannak, vagy azon kívül találhatóak.” (VERNIERO 1936, pp. 4-5)

Verniero, müvének végén, különösen a jogi jelentőségü dokumentumokat említve, hozzáteszi: „más értékes iratok, melyeket az említett Levéltárban örizhettek" (uo. p. 103).

Milyen kéziratokat őrizhettek tehát a levéltárban? Milyen rendszer és milyen (nagyon egyéni és vitatható) kritériumok alapján állíthatták eltünésüket, és nem megsemmisülésüket?

P. Juan de Calahorra, aki 1672-ben Chronica de Syria y Tierra Santa de los Santos Lugares de Gerusalen c. müvében így tájékoztatja „az igen tisztelt olvasót”:

„Az, hogy egyetlen kis kötetben elfért 4 évszázad és 23 év minden története (1219-töl 1632-ig), nem a géniusz hiányának, hanem sajnos (amiröl gyakran írok Krónikámban) a régi szerzetesek hanyagságának következménye, akik nem adták át nekünk az ö idejükböl származó ismereteket, aminek elmulasztásával ( ettöl nem tudjuk felmenteni öket) ily módon megsértik Szeráfi Anyjukat. Ha utódaiknak átadták volna feljegyzéseiket, még ha tele is lettek volna pontatlansággal, 6 kötetre növekedett volna az anyag (ezt megerösíthetem). Nem túlzás az sem, ha arról az elödeink által véghezvitt munkáról beszélünk, ami inkább kötelezte öket, s melyet azokkal a szenvedésekkel pecsételtek meg, melyek a Szent Helyek elvesztésével voltak kapcsolatban. Ha figyelmesen elolvasod krónikámat, megismered és megérted azt a veszteséget, mely abból származik, hogy annyi szerzetes szenvedéseit, köztük vértanúkét is, olyan röviden írták le; ezekben a leírásokban oly sok fájdalmas eseménynek lett volna helye, melyekröl nem találunk semmi más híradást azokon kívül, melyeket a Szaracén Írásokban (dokumentumokban) jegyeztek le. Fenntartom azt, hogy elhanyagolták és nem adták át az utókornak azokat a leírásokat, melyek ezen barbár nemzetek által folytatott üldözésekröl szólnak, de ha annyi különbözö ösi dokumentum és pápai bulla egészen napjainkig megörzödött és fennmaradt ebben a Levéltárban, akkor oly sok más irat elvesztét nem az itt végzett különféle munkákkal, hanem a szerzetesek és az elöljárók hanyagságával magyarázhatom. Ez részemröl nem bírálat, hanem fájdalom amiatt, hogy elmúlt 200 év, és többé nem tudhatjuk az összes szerzetes nevét, néhány elöljáró nevén kivüll. Innen származnak az iratok hiányosságai, nem alkalmazták ugyanazt a módszert a megóvásukra, és innen jön a nevek hiánya is, ami szenvedést okoz nekem; mert ha rendelkezésemre állna a miniszter generálisok neve és az időszak, amikor kormányoztak, azokban az időkben, amikor ezt az egységet Provinciának nevezték, és amikor a provinciálisoknak megvolt az a privilégiumuk, hogy a Sion-hegy gvárdiánjának nevezzék magukat, abban a pillanatban, mikor a Provincia Kusztódia lett és a provinciálisok kusztosokká lettek, s tudnám, mi történt hivatali idejük alatt, fel tudnám osztani müvemet oly módon, hogy pontosan leírjam a történések minden részletét, ahogy azt az elözö négy kötetben tettem, pontosan megírva azt, mi történt az egyes elöljárók megbízatása alatt. Az ismeretek hiánya miatt nehéz ugyanilyen módon folytatni 
a müvet [...] egészen annak Pietro da Monte Piloso kézirataival való lezárásáig [...] és itt további ismereteket találok, melyekről már részletesebben tudok írni." (CALAHORRA 1672, 1v-2r) ${ }^{29}$

Giovanni Bonsignori, Juan de Calahorra kortársa, az 1674. június 14-én elhunyt Claudio Gavazzi da Lodi szentföldi kusztosról írt életrajzi jegyzetében megjegyzi:

„A Kisebb Testvéreknek, a Szeráfi Atya gyermekeinek családja, mely arra hivatott, hogy örködjön az Úr legszentebb sírja és a Szentföld többi helye fölött, áldott életmódot folytatott, mivel az elmúlt századokban szentségükröl nevezetes férfiak tartoztak hozzájuk; életszentségükröl ezeknek a szent helyeknek a története tanúskodik jelenlétük utolsó 362 [évében], és ihlettel szolgálnak a kortárs írók számára, akik a Közel-Kelet történetének ezt a részét írják meg. Többek között a tisztelendö Francesco Gonzaga atya [...] ezt írta.”

Ezután hosszú idézet következik Gonzaga művéből. Majd így folytatja:

„Vannak olyan kortársak, akik pontosan és nagy lelkiismeretességgel feljegyeznek mindent, ami történt, az életmódját és az öltözködését azoknak a papoknak, akik a Közel-Keletnek ebben a részében az életszentség többféle modelljét jelenítik meg, s ezt bemutatják ebben a könyvben, mely feljegyzi nevüket, hazájukat stb., valamint a megholtakat ebböl a lelki családból, feljegyez történeteket is, a szerzetesek erényeit, mi módon szárnyalták túl életmódjukkal a közönséges halandókat, példákat találunk az öltözékükre.” (Registro de Religiosi morti in questa Santa Custodia [ms.], pp. 53-54)

Ebben az időben Bonsignori volt a kusztos titkára; akinek halála után megválasztották a Kusztódia elnökéül, és 1678-ig maradt ebben a hivatalban, az 1675-ös év három hónapjával együtt (vö. GolubOvich 1898, pp. 82-83). Ahogy látjuk, az egész évszázadban a krónikát főleg a régmúlt érdekelte, és nem sok figyelmet fordított a jelenre (vö. CLOU 1891, p. 7; ld. még ARCE 1956, pp. 151155).

Ennek a hanyagságnak magyarázataként érdemes a Rend Általános Konstitúcióit idézni 1663-ból (XII. fejezet, 1.\$, n. 10). Ezt a rendelkezést és megállapítást már más kusztos is kiadta, és a következőképpen hangzott:

„Nevezzenek ki egyet a képzettebbek közül az egész családból, aki elkészíti a figyelemreméltó dolgok és az emlékezetes események krónikáját, melyek napról napra történnek a Szentföldön; hogy ezek a krónikák mindenben igaz dolgokat közöljenek, bizonyos idönként olvassák el és javitsák a Diskretóriumban, és a publikálás elött az eredeti példányt, melyet a gvárdián (kusztos) és a diskretus atyák aláírtak, küldjék el a miniszter generálishoz, hogy az általános káptalan ideje alatt tudott legyen, hogy a fentebb mondottakat pontosan betartották. ”30

29. J. de Calahorra könyvét olasz nyelvre Angelico da Milano fordította, aki a szentföldi provincia gvárdiánja és kusztosa volt. Az első oldalon, mely ,a jámbor Olvasóhoz” megszólítással kezdődik, beszél „a szerzetesek meneküléséröl kolostoruk leégése miatt. De, amennyire tudom, minden pápai bullát és sok kéziratot megmentettek, nagyon régi időkböl valókat is, s ezek majdnem mindegyike most is a Szentföldi Levéltárban található” (CALAHORRA 1694, p. 1).

30 „Unum ex doctioribus totius familiae, qui Annales faciat notabilium et memorandarum rerum de die in diem occurrentium in Terra Sancta, utique hi Annales in omnibus vera referant aliquantis legantur et corrigantur in Discretorio, et autequam pubblicentur, per copiam authenticam a Patribus Guardiano (Custode) et Discretis subsignatam mittantur Ministro Generali, ut tempore Capituli Generali, constet supradicta omnia fuisse adamusssim observata." 
Ezt a rendelkezést hamarosan életbe léptették, és be is tartották.

A külső történések szintén nagy hatást gyakoroltak az iratokra. Ide kell értenünk a különféle költözéseket is, melyek sokszor kényszerüek, ideiglenesek vagy hosszabb ideig tartók voltak: tehát amikor a levéltár nem a saját helyén volt. A költözések azonban az időhiány és egyéb szerencsétlen körülmények következtében úgy mehettek végbe, hogy nem tudták biztosítani a szükséges feltételeket és a kellő elővigyázatosságot, melyek a pergamen és a papír alapú iratok esetében nélkülözhetetlenek. Sajnos teljes bizonyossággal lehet mondani, hogy ezek a tevékenységek sok kritikai megjegyzést érdemelnek. Az elégtétel ezek miatt 1634-ben jött el, és csak tüneti jellegü volt. Számos veszélyes eset után, amikor a testvérek török börtönbe kerültek, a kusztos

„a Szentföldi Levéltár minden kéziratát lepecsételt zsákokba helyezte, és megörzésre átadta a kolostorunkkal szomszédos házban a Salamon nevü tisztelendö maronitának, ahol [...] titkára néhány napig rejtegette azokat”.

A felmerülő helyzet csak azután oldódott meg, hogy bőséges pénzkvótát fizettek a jeruzsálemi török hatalmaknak (VERNIERO in GOLUBOVICH 1930, pp. 208-209).

Amint már láttuk, a XVII. században az Apostoli Szentszék nagy érdeklődést tanúsított a szentföldi levéltár, s különösen annak védelme iránt, ezért 1655-ben megparancsolták, hogy küldjék Rómába az összes eredeti iratot és kéziratot, melyek a szent helyekre stb. vonatkoznak, ,saját levéltár létrehozása céljából" (LEMMENS 1921, p. 181). De amint már megállapítottuk, semmi bizonyosságunk nem lehet afelől, hogy eközben betartották a kötelezően elöírt rendet.

Egyedül azt tudjuk, hogy Francesco Diaz, akit a miniszter generális 1700. szeptember 8-án nevezett ki erre a feladatra, és akinek kinevezését a kusztos 1703-ban megerösítette, a Szentföld kézirati levéltárát a római Szent Főangyalok kolostorban helyezte el. A miniszter generálishoz intézett levelében a következőt írja:

„A Hitterjesztési Kongregáció már régebben elismerte, hogy ki kell építeni egy formális levéltárat, melyben minden olyan dokumentumot és írást örizni kell, melyek valamilyen módon a szent kusztódiára és missziójára vonatkoznak." 31

Az ún. demokratikus kormányzat idején Rómában az 1798-1799-es években a Szent Főangyalok kolostorában olyan levéltárak összegyüjtött anyagát őrizték, amelyeket megsemmisítettek vagy szétszórtak (vö. LEMMENS 1924, pp. 39, 46-47).

A XVIII. században hasonló helyzet állt elő. Nagy jelentősége volt Lorenzo Cozza kusztos 1714. július 15-ére datált rendelkező levelének, amelyben a dolgok akkori állását írja le:

„Az elöljárók hanyagsága miatt nincs információnk a Kusztódia számára legjelentösebb eseményekröl, melyek a Gvárdián Atya kormányzásának végén történtek; azt is gondolom, hogy a lelkipásztori haszon érdekében érdemes rendbe tenni a különféle házak jegyzékeit, feljegyezve minden olyan dolgot, amit tudni kell."

Érdemes idézni a levél egy másik részletét is:

„Végül nem érdemes mindenben az elmúlt idők hanyagságát hibáztatni, melyre Kusztódiánk hivatkozik, válaszul az Apostoli Szentszék szemrehányásaira a sok dokumentum hiánya miatt. [...] azt akarjuk, hogy minden kolostorunk és szálláshelyünk helyi elöljárói vezessenek könyvet a mi rendelkezéseink szerint

31 „Sacra Congregatio de Propaganda Fide jampridem censuit, quod construi debeat archivum formale, in quo asservatur omnia monumenta et scripta ad sanctam custodiam ac illius missiones quoquomodo spectantia" (DIAZ 1717, n. 463, 469). 
[...]. Legyen egy másik könyv is, vagy annak egy része, ahova bejegyzik az alamizsnát [...]. Harmadszor pedig legyen egy könyv vagy annak egy része, ahova a helyi elöljárók feljegyeznek minden jelentös történést. Ha az említett könyvek betelnek, küldjék el azokat Jeruzsálembe, hogy az új levéltárban örizzék azokat. Senki ne csodálkozzon ezen a rendelkezésünkön, mivel az utolsó öt év tapasztalatai megmutatják sok már említett emlék hiányát, melyet a Szentszéknek egyedül azzal az irigységgel és üldözéssel magyarázhatunk, mely szegény Kusztódiánkat ellenségei részéről éri. Mivel biztosak vagyunk ezen rendelkezés helyessége felöl, utasítjuk a helyi elöljárókat, hogy adják ezt tudtára minden szerzetesnek, akik ezekkel a könyvekkel fognak foglalkozni, nyolcnapos határidőn belül, melyet nem lehet túllépni: az elsö könyv címlapjára fel kell írni: 'Általános jegyzék', a másodikéra - 'Adományok jegyzéke', ahol meg kell említeni az irgalmasság cselekedeteire és a sürgös esetekre adott kiadásokat; a harmadik könyv címlapjára - 'Eredmények és jelentös események jegyzéke’. El kell készíteni ezeknek a könyveknek a másolatát is, erre a célra át kell adni mindhárom könyvet az utódunknak, kézböl kézbe, megbizatásunk végén. Ne okozzon kárt a Kusztódiának és az egész Rendnek az ilyen szükséges és hasznos dolog tudásának hiánya." (CASTELLANI 1924, pp. 346-348)

Ez a nagyszerü rendelkezés már Cozza kormányzásának elején megteremti a hiányok megszüntetését szolgáló kontroll lehetőségét azzal, hogy meghatározza az időt, és a rendelet végrehajtásának pontos felügyeletét. Így hát 1715. április 15-én, mandátumának lejárta után Cozza Rómába utazik. Dicséretére legyen mondva, hogy nem olyan ember volt, aki csak másoknak ad ki rendelkezéseket: a maga részéről tekintélyes mennyiségü dokumentációt hagyott a levéltárra saját kormányzásának idejéről, melyet Eutimio Castellani publikált két kötetben, és amelyben 949 oldalon 607 iratot mutatott be.

Lorenzo Cozza lemondási szándékáról 1728-ban Giacomo Lucca kusztos tájékoztat ezekkel a szavakkal:

„Tisztelendő Cozza atya a Szentföld ötéves kormányzása után 1714. július 15-i rendeletében közzéteszi, hogy a szükséges információk hiánya miatt nem tudja tovább folytatni szolgálatát, mert nem képes visszaszerezni az Apostoli Szentszéknél a szegény Kusztódia becsületét és a Szentszék róla alkotott jó véleményét, miután Kusztódiánkat ellenségei irigységböl befeketítették. Mindez megmutatta nekem, milyen fontosak a Szentföld jó kormányzásához ezek az információk; tehát megígérem utódaimnak, hogy visszaszerezzük a jó véleményt, $s$ ök nagy nehézségek nélkül megkaphatják a szükséges információkat.” (Atti Discretoriali. Reg./B, 13; vö. LEMMENS 1933, p. 273)

Úgy tünik tehát, hogy Giacomo da Lucca minden gondja az volt, hogy Sion szent hegyének levéltárát 1726-ban átalakítsa és leltározza, ahogy ez a fentebb idézett beszámolóból kitünik. Ezt a nagyon komoly munkát tehát Giacomo da Lucca vitte végbe, aki 1723-1728 között volt szentföldi kusztos, és fundator archivi vocari potest, azaz „a levéltár alapítójának mondható”, ahogy erről Leonhard Lemmens tanúskodik (az átalakításról ld. CASTELLANI 1929, pp. X-XI; vö. LEMMENS 1933, p. 245).

Negyven évvel később Paolo Volpini da Piacenza szentföldi kusztos (1762-1767) ezt írta saját mentségére az egyik kódexben:

„Levelek, rendelkezések, utasitások és egyéb fontos dolgok jegyzéke Paolo da Piacenza testvér, Sion szent hegyének gvárdiánja, szentföldi kusztos 
kormányzásának végéig. Ezt a jegyzéket abból a nagy szükségböl készittették, hogy teljességében és hüen örizzék meg mindennek a másolatát, amit minden nagy jelentöségü dolog elintézésének folyamán írásba foglaltak. Sajnos nem tudunk mindenröl másolatot készíteni, mivel kormányzásom végén magam vettem észre számos nagy jelentöségü irat másolatának hiányát. Köszönöm Istennek, aki mindig segít nekem, hogy becsülettel és elövigyázatosan, mégis aggodalom nélkül irjak. Ezt azért mondom, hogy minél elöbb megkapjam ezeknek az írásoknak a másolatát az emlékiratok számára, és nagyobb hasznára mindazoknak, akik ezeket az iratokat tanulmányozzák.” (PIANA 1944, pp. 49)

Köszönetet érdemel pontossága, amivel megőrizte a Kusztódia számára az összes kéziratot, amelyek nem csak az ő magánügyeit érintik; még inkább dicséretre méltó az a vágya, hogy ezt a lehető legjobb módon végezze, amiről papíralapú kéziratok két bőséges kötete tanúskodik (pp. 168-299), mutatva jó szándékát. De mire gondolt, amikor arról beszélt, hogy „nagyobb hasznára mindazoknak, akik ezeket az iratokat tanulmányozzák”? Megbízatásának lejárta után, úgy tünik, elvitt Itáliába két kötetet, melyeket ma is a bolognai Szent Katalin kolostor kúriáján őriznek (vö. PIANA 1944, pp. 4950).

Hasonlóan jártak el a többi kusztosok is: általánosan legalább két ilyen eset ismert. Az egyik Teofilo Testa da Nolához kapcsolódik (a nápolyi provinciából), aki a Kusztódia elnöke volt 1669-ben, majd szentföldi kusztos 1670-1673 között, s akinek érdeme a levéltár számára az anyakönyvezés szigorítása volt. Amikor visszatért Itáliába, 65 iratot vitt magával, köztük 18, európai uralkodóktól származó eredeti példányt. Mindegyik irat a Szentföldre vonatkozott, azokból az időkből, amikor ő volt az elöljáró. Jelenleg Nápolyban, a Santa Maria la Novában, a provinciai levéltárban őrzik ezeket. ${ }^{32}$

A második eset Pier-Marino Sormani nevéhez füződik (a milánói provinciából), aki 1678-1682 között volt szentföldi kusztos, és akit a Rend miniszter generálisává választottak. Később a lombardiai Vigevano püspöke volt, ott is halt meg 1702-ben. A vigevanói püspöki hivatal levéltárában őrzik gazdag kéziratát (8 rész 288 oldalon), mely kusztosként írt naplóját tartalmazza, valamint gazdag dokumentációt a Kusztódiára vonatkozóan azokból az évekből (1678-1682). ${ }^{33}$

Megvan az értelme e három eset említésének, mivel ez a teljes hivatalos dokumentáció a Szentföldi Kusztódiáé, nem az egyes emberé, függetlenül attól a pozíciótól, melyet az adott struktúrában betölt. Nem helyes, hogy ez a dokumentáció nem ott található, ahol a legtermészetesebb helye lenne: a Szentföldi Kusztódia Történeti Levéltárában. ${ }^{34}$

Mindig megfelelően feljegyezve a Jeruzsálemi Levéltár iratainak hiányát, P. Cirelli, aki személyesen foglakozott ezzel 1857-1859 között, ezt a figyelemre és bizalomra méltó magyarázatot adja:

„Úgy tünik nekem, hogy a levéltárban található, 1670 elôttről származó eredeti kéziratok nagyon kis számban vannak és majdnem értéktelenek, és semmi nem kényszeríthet arra, hogy megváltoztassam a véleményemet [...]. Mert mivel magyarázzuk az eredeti kéziratok teljes hiányát a Jeruzsálemi Levéltárban annak a korszaknak a végéig, melyben P. Wadding írt, vagyis az 1644-es évvel bezárólag?” (CIRELLI 1918, pp. 20-21)

32 Teofilo Testa kusztosi kormányzásáról ld. GoLUBOvich 1898, p. 81; a titkársági jegyzékekről ld. LeMmENS 1933, pp. 245, 255-271; vö. D'ANDREA 1962, pp. 24-25, 28-33.

33 Kusztosi kormányzásáról ld. GOLUBOVICH 1898, pp. 83-84; valamint DROVANTI 1908, pp. 475-477.

34 Az előző levéltáros, Metodio Brlek és testvére, Cecilio közbelépésének köszönhetően, akiknek sikerült lemásolniuk mindhárom iratcsomagot, ezeket a másolatokat jelenleg levéltárunkban örizzük. 
Benigno da Genova, a Rend miniszter generálisa 1619. április 20-án nagyon sikeresen utasította a tartományfőnököket, hogy a lehető leggyorsabban gyüjtsék össze tiszteletreméltó provinciájuk történelmi iratait és küldjék azokat Rómába. 1639. június 24-én Francesco Barberini bíboros, a rend protektora megerősíti azt az ajánlást a tartományfőnökök felé, hogy adják meg a lehetőséget P. Luke Wadding, a rend krónikása számára, hogy felhasználhassa az iratokat a Rend évkönyveinek létrehozásához. A Rend általános káptalanja, melyet 1645-ben Toledóban tartottak, meghagyta a tartományfőnököknek, hogy küldjék Rómába a történelmi anyagokat, melyek nélkülözhetetlenek Gonzaga mủvének folytatásához. ${ }^{35}$

Az elmúlt évszázad Kódexének elején ezt olvassuk:

„Jegyzőkönyv a Küldött és Kapott Fontos Levelekröl az 1841-es és az 1860-as évek között",

a címoldalra ezt van írva:

„Tiszteletreméltó Cherubino Maria da Cori kormányzásának kezdete, Szentföldi Kusztos 1841-töl”,

más kézírással pedig hozzátették:

„Megszakítva az utódok által a gondoskodás hiánya miatt; megújítva 1844. november 13-án."

Látjuk, hogy ez az egyetlen említés, ami a levéltár nagy hiányosságait magyarázza, melyek a meghatározott történelmi korszakokat érintik, de igen jelentős a hozzáfüzött „hanyagság miatt” kiegészítés, mely részben az akkori titkárságra vonatkozik. Ma megállapíthatjuk, hogy igazolt nagy hiányok föként az Ügyvivők Aktájában találhatók, melyek az 1857-1863, ill. az 1869-1873 stb. közötti éveket érintik.

Luigi da Parma miniszter generális Általános Rendelkezések a Szentföldi Kusztódia Nagyobb Hasznára c. írásában, melyet vizitációja alatt, 1893. augusztus 19-én adott ki, a 8. pontban ilyen utasítást ad:

„Minden helyi elöljárónak legyen egy könyve, melybe nap mint nap beírja a jelentös eseményeket, melyek a neki alárendelt konventben történtek. Javasoljuk ezt teljes pontossággal végezni, és megtiltjuk, hogy megsemmisítsék ennek a krónikának azon oldalait, melyeket elödeik írtak, amikröl sajnos vannak tapasztalataink. ${ }^{\text {"36 }}$

Hozzátehetjük, hogy ezt az utasítást betartották a Kusztódiában mint normát (vö. Cozza kusztos 1714ben kiadott hasonló rendelkezésével) - ezek a krónikák a levéltár hatáskörébe tartoznak.

Nem kell aggályosan felsorolni ebben a témában minden apróságot, melyek a XIX. században is előfordultak. Elég azt mondani, hogy ezek a problémák nemcsak a XVIII. században léteztek. 1920. szeptember 19-én Ferdinando Diotallevi kusztos ezt írja:

„Nem tudom, hogy jelentős vagy jelentéktelen okból, a Kusztódia Krónikája, mely a történetírás alapja, az 1859-es évvel megszakad, leírásaiban sok kimagasló eseményt is kihagy, amelyekről nem találunk korábbi információkat. Ezt a sajnálatraméltó ürt a lehető leggyorsabban ki kell tölteni, maximális pontossággal (amennyire ez lehetséges), mivel ez nagy segítséget jelent a történetírásban. Amikor 1918-ban átvettem a kormányzást ebben a Szent

\footnotetext{
35 A három idézett dokumentumot a következő műben publikálták: WADDING 1935, pp. XII-XVII.

36 Az egyszerü feljegyzés egy nyomtatott lapocskán található L. da Parma iratai között.
} 


\section{Kusztódiában, komoly hiányosságokat fedeztem fel a dokumentációban, tehát elkezdtem megfelelö Testvért keresni, akinek megfelelöen nagy a türelme, és alkalmas ennek a munkának az elvégzésére. Hála Istennek sikerült rátalálnom Eutimio Castellani da Cave atyára."}

Castellani valóban nagy pontossággal teljesítette ezt a feladatot és kiegészítette a Szentföldi Krónika négy nagy kötetét, melyek az 1859-től 1937 áprilisáig terjedő időszakot ölelik fel. ${ }^{37}$

Mialatt iratokat keresett a Szentföld kolostoraiban és a Kusztódia házaiban Közel-Keleten, sajnos nagyon gyakran kellett szembesülnie a krónikák hiányával. Vajon mihez kezdett ezzel? Hogy lehet magyarázatot adni arra, hogy egyes házak elöljárói házfőnökségük teljes hat éve alatt nem írtak egy szót sem a krónikába? Annak ellenére, hogy a miniszter generálisok és a kusztosok mindig erre köteleztek mindenkit!

Levéltárunk hiányosságait mindenekelőtt az okozta, hogy az elöljárók részéről hiányzott a kellő gondoskodás - ezt a körülményt már sokszor említettuik. Ezért csak az a megoldás maradt, hogy lehetöség szerint feljegyezzék a közvetlen szóbeli bizonyítékokat, melyek közül szinte egyet sem publikáltak régebben, de most először felhasználták azokat, a dokumentált bizonyítékokkal együtt. Elég szomorú tapasztalat volt ez azokban az időkben.

A levéltár nem raktár és nem bánya, hanem „élő szervezet”, mely leképezi az életet az ő közvetlen kisugárzásában. Ezért nem lehet abbahagyni a levéltár rendezését egy időre, mivel az komoly hiányosságokhoz vezet, melyeket nehéz bepótolni. A történelem nem válaszol azon frissiben, mint egy interjúban, hanem idő kell a válaszaihoz, melyeknek - ha bekövetkeznek - nagy értékük van.

\section{A megbízott levéltárosok}

Miközben leírjuk azok feladatát, akiket a levéltár gondozására küldtek, emlékezni kell arra, hogy a levéltár nem egy pillanat alatt jött létre, hanem majdnem öt évszázad folyamán, az akkor kormányzó kusztosok közvetlen és különös gondoskodásával, akik az iratokat vagy a saját szobájukban, vagy ahhoz nagyon közel- majdnem kéznyújtásnyira - őrizték. Az őrzésnek ez a módja garantálta a legnagyobb biztonságot az iratok számára. Mégis meg kell jegyeznünk, hogy egyrészt nem minden kusztosnak volt ideje arra, hogy kellő módon gondoskodjon a levéltár megfelelő folyamatosságáról. Másfelől ezen nem kell csodálkozni, mert pl. 1669-ben a Rend Általános Konstitúciója, mely többek között a rendtartományok levéltárairól való rendelkezés kérdését tárgyalja (XII. fejezet, 23. §, n. 1), megemlíti, hogy két kulcsnak kellett lennie a levéltárhoz: az egyik a tartományfönök, a másik a provinciai anyaház elöljárójának rendelkezésére kellett, hogy álljon. Ebben a konkrét esetben nehéz megmondani, hogy a Kusztódiában ki tartotta magánál a második kulcsot. Lehetett a titkár (ahogy ez ma a gyakorlat), mivel a fökolostorban mindig ott lakott a kusztos, ami miatt a legmegfelelőbb személy a második kulcs őrzésére a titkár volt.

Érdekes az a feljegyzés a XVIII. század első feléből, mely bemutatja a sajátosan a P. Guardiani Hierosolymitani titkárát érintő veszélyeket, és hozzáteszi:

„Hasonlóképpen, ha nincs más, egy különösen képzett pap krónikásként köteles szorgalmasan feljegyezni a szentföldi testvérek tetteit, az írásokat hüen örizni a

37 F. Diotallevi szövege, mely E. Castellani Szentföldi Krónikák c. müve első kötetének elején található. Nem vonhatjuk le a következtetést ennek a kijelentésnek az abszolút jellemző voltát illetően, mivel Diotallevi bizonyos „,örténeti” forrásokra támaszkodik, hogy megírhassa a letűnt idők krónikáját... Különösen az első kötetben hivatkozik Castellanira, az 1859-1887-es évekhez különböző, ma már nem létező iratokból ollózza össze az anyagot. Diotallevi kusztos kezdeményezése nem valósult meg teljesen. 
levéltárban, elhelyezni azokat a megfelelö helyen, hogy a kartoték segítségével könnyebben meg lehessen azokat találni.” (HORN 1902, p. 236, 33. lábj.)

Ez a feljegyzés arról szól, hogy a titkár volt a felelős a levéltár fenntartásáért a XVIII. század 70-es éveiben. Ismerünk ideiglenes kinevezéseket is a levéltári munkára, mint pl. 1634-ben P. Verniero esetében, akit már sokszor említettünk; ilyen küldetést kapott Gdański Bonawentura is 1724 januárjában (1730. április végéig) (vö. LEMMENS 1933, pp. 273, 286).

Erről ír Giacomo da Lucca kusztos 1728-ban:

„A miniszter generális úgy rendelkezett, hogy küld egy szerzetest, aki a Szentföld Levéltárával és irataival foglalkozzon, és nem csak azért, hogy kellö rendben tartsa azokat, hanem hogy ábécésorrend szerint rendezze azokat, mert ez nagyban megkönnyíti a Szentföldre vonatkozó iratok használatát, és megtakarítja a keresésükkel töltött időt.” (Uo. 273)

Ennek a szerzetesnek feltétlenül beszélnie kellett a titkárral, hogy pontosan megismerje az irodát és a dokumentációt, különösen a XVII. század elejére datálható kéziratokat. Hogy megtaláljuk azokat az „ízig-vérig” levéltárosokat, akik a lehető legjobban tudták teljesíteni szolgálatukat, az 1868-as, majd az 1882-es évekre kell tekintenünk. A hivatal mindemellett csak 1918 után lett állandó jellegü.

A Szentföld Levéltárában őrzött kéziratokban említést találunk XVII. századi levéltárosokról. Augustín Arce például említést tesz Juan de Calahorráról ${ }^{38}$ és a Kusztódia egy másik levéltárosáról, Francesco de San Juan del Puertóról is. ${ }^{39}$

Ezeket az értesüléseket nem erősítik meg hivatalos kusztódiai iratok, de 1868-ban a Prospectus locorum et Religiosorum Ordinis Minorum S. Francisci Custodiae Terrae Sanctae-ban az Ufficiales Curiae-k között ezt az idézetet találjuk:

\section{„P. Jucundinus Bielak Ref. Prov. Poloniae, Penitentiarius Apostolicus Linguae} Polonae, Archivista et Scriptor. "40

Kicsit később, 1882-ben találunk egy másik közlést a status personalis-ról, mely így hangzik:

„Officialis Curiae, R. P. Alphonsus-Maria Girelli a Verona, Observ. Prov. S. Antonii Venetiarum, Miss. Apost. Pro-Penitentiarius pro Italis, Archivi Custos, Chronologus Terrae Sanctae et Casum Conscientiae actualis Explanator. "41

A Rendelkezések Aktájában 1918. május 23-án megemlítik, hogy a Kusztódia levéltárosává Castellanit nevezték ki; később található egy beírás 1918. december 30-áról, amely részletezi a levéltáros kötelességeit:

38 Augustín Arce így ír Juan de Calahorráról: „Archivero de la Custodia por muchos anos y Cronista oficial de la misma, escribió su Chronica de la Provincia de Syria y Tierra Santa, Madrid 1684, durante los anos 1662-1684” (ARCE 1978, p. 106); „Esta Chronica, manuscrita e inédita, es la continuación de la de Calahorra y abraca los anos 1632 a 1700. De ella poseo una fotocopia y estoy preparando la edición. El autor fue archivero de Jerusalén y Procurador general de Tierra Santa” (MONTOYA in ARCE 1975, p. 220, 3. jegyzet).

39 P. Augustín Arce a Kusztódia egy másik levéltárosáról, P. Francesco de San Juan del Puertóról: „también fue archivero de la Custodia hacia 1718-1724" (Patrimonio Seraphico de Tierra Santa 1724; vö. ARCE 1975, p. 220, 4. jegyzet).

40 Prospectus locorum et Religiosorum Ordinis Minorum S. Francisci Custodiae Terrae Sanctae 1868, p. 5. A 9. oldalon, a San Salvatore kolostorra vonatkozó történelmi megjegyzésben különféle kapcsolódásokat találunk a következőkhöz: Bibliothecam, Archivia, Typographiam.

41 Status Personalis Religiosorum in Alma Seraphica T. S. Custodia actualiter degentium juxta peractam dispositionem in Intermedia Custodiali Congregatione die XXVII, Septembris (1882). Hierosolymis habita, p. 5 . 
„Rendben kell tartania azokat (minden iratot, mely a Szentföld tulajdonában van), katalogizálni és tanulmányozáshoz hozzáférhetôvé tenni, valamint használatra bocsátani azokat a katalógusból.” (Atti Discretoriali. Reg. K/R 1913, 190, 221).

A Szerzetescsaládok a Szentföldi Kusztódiában, melyet 1921-től napjainkig háromévente jelentetnek meg nyomtatásban, nyolc kusztódiai levéltárost említenek:

1921-1926: Eutimio Castellani

1926-1931: Rafaelle Casali (6 év levéltárosi szolgálat)

1931-1934: Antonio Gassi (3 év szolgálat)

1934-1937: Ambrogio Cirilli (3 év szolgálat)

1936-1937: Giuglio Zanella, Noël Gosselin levéltáros-helyettes

1937-1946: Eutimio Castellani (összesen 16 év szolgálat)

1946-1950: Filadelfo Congioli (4 év szolgálat)

1950-1963: Basilio Talatinian (12 év szolgálat)

1963-1998: Metodio Brlek (35 év szolgálat!)

1998-tól: Narcyz Klimas.

\section{A dokumentáció általános jellemzése}

Nem tekintve a sok megmagyarázható és megmagyarázhatatlan hiányosságot, a Szentföld Történeti Levéltára mindmáig nagy jelentőségü levéltár nemcsak Golubovich idézett véleménye nyomán, hanem mindenekelött egyes gyüjteményei miatt, melyek történelmi-földrajzi tárgyú, valamint a katolicizmusra vonatkozó iratokat tartalmaznak. Ennek a levéltárnak kiemelkedő jelentőségéről tanúskodik az a tény, hogy olyan híres levéltárakban, mint a párizsi, a velencei, a vatikáni (különösen a Hitterjesztési Kongregációé), a Szentföldi Kusztódiára vonatkozó iratok is vannak, különösen az ún. „,szekuláris” részt - föleg a Kusztódia, az európai hatalmak és az Apostoli Szentszék közötti levelezést - érintők.

Ami a levelezést illeti, amelyet a Szentföld Történeti Levéltárában őriznek, két korszakra kellene osztani attól függően, hol volt megtalálható: Sion-hegyi korszakra (XIV-XVI. sz.); és San Salvatore kolostorbeli korszakra (XVII-XXI. sz.).

Az első korszakban, mely kb. kétszáz évig tartott, majdnem minden kívülröl jövő jogi iratot megőriztek. Ezek pápai bullák, hivatalos és magánjellegü iratok, föleg arab nyelven. Tartalmuk alapvetően megerősítés, autorizáció, rendelkezés, valaminek a létesítése, hivatalos elismerés, bírósági ítélet, tulajdonjogi dokumentumok, civil és egyházi határozatok, adásvételi elismervények stb.

Nehéz lenne megmondani, ki és mikor gyüjtötte össze és őrizte meg ezeket, különösen ha a XIVXVI. században élő testvérekre gondolunk, akik majdnem kizárólag a jogi iratokkal foglalkoztak, mivel ez adta meg az élet és a működés lehetőségét inter infideles. A fennmaradt anyagból úgy tünik, egyáltalán nem érdekelte őket semmi más.

A második korszakban, mely a XVII. században kezdődött és ma is tart, megőrizték a teljes jogi dokumentációt (amit folyamatosan megújítanak és kiegészítenek), amely a jogi és adminisztratív iratok legkülönbözőbb fajtáit tartalmazza, és amelyek elbeszélö jellegúek és gyakran csak kiegészítések. Feljegyezték, hogy a XVII. századtól kezdve a missziós élet és tevékenység a 1622. 
január 6-án létrehozott Hitterjesztési Kongregáció rendelkezéseinek befolyása alatt szerveződött és fejlődött. Ezt a szervezett tevékenységet, mely sok praktikus formában öltött testet, tartalmazza a különféle „bejövő és kimenő” dokumentáció.

Ekkor új kihívások, új problémák vetődtek fel, az iratokra pedig akkoriban nagyobb figyelmet kellett fordítani, hiszen gyakran ezek jelentették az egyetlen védelmező erejü bizonyítékot nemcsak elméletben, hanem a gyakorlatban is. Ezek biztosították ugyanis az élet, a mozgás és a munka lehetőségét, és ezzel együtt a lakhelyet, hiszen ezek a dokumentumok egyben azt is bizonyították, hogy az adott épületek és területek a Szentföldi Kusztódiához tartoznak.

Tehát amikor a XVII. században meghatározták a Kusztódia belső struktúráját minden szükséges jellegzetességével együtt, ez különösen érintette a katolikus világban egyre szaporodó szentföldi komisszáriátusokat, amelyek ebben az időben kaptak teljes jogi státuszt, amire a jövőben aztán hivatkozni is fognak. Ezek a körülmények, mint ismeretes, új levéltári anyagot hoztak.

Szintén érdemes felidézni, hogy a XVII. század folyamán az akkori ferencesek érdeklődése megnövekedett a rendi levéltár iránt. Elég az Általános Konstitúciókat, az 1663-as ún. Sambucane-t idézni, ahol a XII. fejezet 23. §-ában (6 pontra van osztva) említést találunk a témáról (vö. De Archiviis Provinciarum, et Conventuum) ${ }^{42}$

\section{Statisztikai elemek}

Végül el kell ismerni, hogy a két korábban említett korszak különböző mennyiségủ dokumentációja statisztikai rendszerezést tesz szükségessé a testvérek és a konventek száma szerint, akik a különböző korszakokban a Szentföldi Kusztódiához tartoztak. Az iratok keletkezési helyének és idejének ismerete rendkívül fontos a levéltár rendszerezésénél.

Nézzük mindenekelött a kolostorokat. Ha vita tárgyát képezheti annak dátuma, mikortól laknak a Szentföldön állandó jelleggel a ferencesek (ez az esetek többségében Jeruzsálemre vonatkozik), akkor annak a hivatalos egyházi intézménynek, melyet Szentföldi Kusztódiának hívunk, 1342. november 21én van a születésnapja (VI. Kelemen pápa Gratias agimus kezdetủ bullája). Az első két kolostorhoz (a Szent Sír bazilikában és a Sion-hegyen lévőkhöz) hamarosan két következőt csatoltak: a Szent Katalin kolostort a betlehemi Születés bazilika közelében és a Legszentebb Üdvözítő kolostort Bejrútban (Libanon). A XVI. század végéig a Szentföldi Kusztódiának csak ez a négy helye vagy konventje volt.

A XVI. század elején a Kusztódiához tartozott Cipruson a nicosiai kolostor is, de ezt bezárták, amikor a szigetet 1571-ben elfoglalták a törökök; majd az 1571-es lepantói csata következményeként elvesztették a bejrúti konventet is. A XVI. század vége felé azonban megfigyelhető a ferences jelenlét Cipruson és Libanonban, s ugyancsak jelen vannak a rendi élet és apostoli tevékenység többé-kevésbé stabil formái Egyiptomban és Szíriában is, melyek sok helyhez kapcsolódnak. Létezett ház Konstantinápolyban is.

A következő évszázadban a Palesztinával szomszédos államokban sikerült stabilizálni és fejleszteni a rendi élet és apostoli tevékenység előző évszázadból átvett formáit, hét új alapítás is született. A XVII. században már 17 ház van, melyek - a Szentföldön kívül - Cipruson, Libanonban, Szíriában és Egyiptomban találhatók. A század vége felé számuk már eléri a 20-at.

1911-ben, az első világháború előtt, a Szentföldi Kusztódia 57 házat számlál, melyeket jogállásuk szerint kolostorokra, hospitiumokra, residentiákra és missziókra oszthatunk.

\footnotetext{
42 A jogi dokumentumokról és más, a Szentföldi Levéltárra vonatkozó információkról ld. KLIMAS 2013.
} 
Nézzük csak a testvérek számát a különböző századokban. A Szentföldi Szabályzat 1377-ben nem több mint 20 testvérről tesz említést, akik a Szent Sír bazilikában, Betlehemben és a Sion-hegyen laknak. 1414-ben kb. ugyanennyi a számuk. 1482-1483-ban 3 lakott hely van összesen 32 testvérrel. Az 1523-as Tabula Terrae Sanctae 51 testvért említ, akik az ún. Szentföldi Család tagjai.

1563-ban már 55 testvér van. 1604-ben a Család csak 46 tagot számlál; 1627-ben azonban 63-an vannak (sőt lehet, hogy még többen). A XVII. század vége felé a Kusztódiában 201 szerzetes él!

A Szentföldi Szabályzat 1746-ban - nagy matematikai pontosság nélkül - 160 szerzetesröl tesz említést. A Kusztódia személyi állománya 1856-ban 218 szerzetesből áll. 1911-ben a szerzetesek száma már eléri a 477-et!

Ennek a rövid statisztikai információnak nem az a célja, hogy a levéltár értékelésének kritériumát nyújtsa, hanem hogy az adatokat ismertessen. Kiindulópont lehet a kolostorokból és a testvérektől származó iratok származásának jobb megértéséhez is, amelyek a Szentföldi Kusztódia Történeti Levéltárában találhatók. ${ }^{43}$

\section{Irodalom - References}

ARCE, A. (1983): Archivio Storico della Custodia di Terra Santa. In: M. PICCIRILLO (ed.): La Custodia di Terra Santa e l'Europa. I rapporti politici e l'attività culturale dei Francescani in Medio Oriente, Il Veltro, Roma.

ARCE, A. (1978): Juan de Calahorra. Archivum Franciscanum Historicum, 71: 106.

ARCE, A. (1956): Le P. Leonard du Clou OFM. Ancien Discret Custodial de Terre Sainte. La Terre Sainte, (Sept.-Oct.), 151-155.

ArCE, A. (1975):Miscelánea de Tierra Santa, t. 3., Ex Archivis Terrae Sanctae 9., Franciscan Printing Press, Jerusalem.

AVEIRO, P. de (1927): Itinerário da Terra Santa e suas particularidades. Universidade, Coimbra.

BORE, E. (1850): La Questione dei Luoghi Santi. Soc. Tip. Maltese, Malta.

BrÉHIER, L. (1907): L'Église et l'Orient au Moyen Age. Les Croisades. Victor Lecoffre \& J. Gabalda, Paris.

BatTistelli, G. (2003): Giovanni Battistelli szentföldi kusztos levele a Kusztódia helyi elöljáróinak. I.sz. 0013/04.

CAlahorra, J. de (1672): Chronica de Syria y Tierra Santa de los Santos Lugares de Gerusalen. Madrid.

Castellani, E. (1924): Atti del Rev. mo Padre Lorenzo Cozza, Custode di Terra Santa (1709-1715). vol. 1. In: G. Golubovich (ed.): Biblioteca Bio-Bibliografica della Terra Santa e dell'Oriente Francescano, II Serie, Documenti 4., Quaracchi, Roma.

Chateaubriand, F. R. de (1871): Itinéraire de Paris à Jerusalem. Alfred Mame et Fils, Tours.

CIRElli, A. (1918): Gli Annali di Terra Santa. S. Mencherini e Bibliografia di Terra Santa del medesimo, Quaracchi, Roma.

Clou, L du (1891): Itinerarium breve Terrae Sanctae. E. Ariani, Firenze.

D’ANDREA, F. G. (1962): P. Teofilo Testa da Nola OFM. Custode di Terra Santa e Vescovo di Tropea, Cenacolo Serafico, Napoli.

DIAZ, F. (1717): Lucerna Hierosolymitana. Roma.

Drovanti, L. (1908): Diario ed altre memorie di Fra Pier Sormani Marino, Custode di Terra Santa nel 16781682. Archivum Franciscanum Historicum, 1: 475-477.

GonZAGa, F. (1587): De origine Seraphicae Religionis Franciscanae. Ex Typographia Dominici Basae, Roma

GUARMANI, C. (1872): Gl'Italiani in Terra Santa. Fava \& Garagnani, Bologna.

43 Statisztikai adatokat, különösen a legutóbbi időkből származókat, a Szerzetescsaládok jegyzékében is idéznek, a Tabula Terrae Sanctae-ban más történelmi források is vannak, melyeket levéltárunkban találtak. 
Golubovich, G. (1898): Serie Cronologica dei Reverendissimi Superiori di Terra Santa. Jerusalem.

Golubovich, G. (1909-1912): Biblioteca Bio-Bibliografica della Terra Santa e dell'Oriente Francescano, vol. 5., Annali di Terra Santa dal 1346 al 1400. Quaracchi, Firenze.

HORN, E. (1902): Ichonographiae locorum et monumentorum veterum Terrae Sanctae, Typis Sallustianis, Roma.

KLIMAS, N. S. (2012): La Custodia di Terra Santa ed il suo Archivio. In: A. MAIARELli (ed.): L'Archivio Storico della Custodia di Terra Santa (1230-1970). Biblioteca Bio-Bibliografica della Terra Santa e dell'Oriente Francescano, Quinta Serie, Sussidi 30., Introduzioni. Milano, 77-118.

Klimas, N. S. (2013): La Storia dell'Archivio Storico della Custodia di Terra Santa. Edizioni Terra Santa, Milano.

Lemmens, L. (1921): Acta Sacrae Congregationis De Propaganda Fide pro Terra Sancta. In: G. GolubOVICH Biblioteca Bio-Bibliografica della Terra Santa e dell'Oriente Francescano. II Serie, Documenti 1., Quaracchi, Roma.

LEMMENS, L. (1933): Collectanea Terrae Sanctae. Ex Archivo Hierosolymitano deprompta. In: G. GoLUBOVICH (ed.): Biblioteca Bio-bibliografica della Terra Santa e dell'Oriente francescano, Serie II., Documenti. 14., Quaracchi, Roma.

Lemmens, L. (1924): De sorte Archivi generalis Ordinis Fratrum Minorum e Bibliothecae Aracoelitanae tempore Reipublicae Tiberinae (an. 1798-1799). Archivum Franciscanum Historicum, 17: 30-54.

MaiARElli, A. (ed.) (2012a): L’Archivio Storico della Custodia di Terra Santa (1230-1970). vol. 1., Introduzioni. Biblioteca Bio-Bibliografica della Terra Santa e dell'Oriente Francescano. Quinta Serie, Sussidi 30., Edizioni Terra Santa, Milano, 2012.

Maiarelli, A. (ed.) (2012b): L'Archivio Storico della Custodia di Terra Santa (1230-1970). vol. 2., Inventario dell'archivio della Curia custodiale. Biblioteca Bio-Bibliografica della Terra Santa e dell'Oriente Francescano. Quinta Serie, Sussidi 31., Edizioni Terra Santa, Milano, 2012.

MAIARELli, A. (ed.) (2012c): L'Archivio Storico della Custodia di Terra Santa (1230-1970). vol. 3., Inventario degli archivi aggregati, case religiose, parrocchie. Biblioteca Bio-Bibliografica della Terra Santa e dell'Oriente Francescano. Quinta Serie, Sussidi 32., Edizioni Terra Santa, Milano, 2012.

Mislin, J. (1876): Les Saints Lieux. Pèlerinage à Jérusalem. vol. 2., Lecoffre, Paris-Lyon.

Mombelli, A. (1934): La Custodia di Terra Santa. Tip. dei PP. Francescani, Jerusalem.

MontoyA, A. de (1719): Chronica de la Custodia de Syria y Tierra Santa.

Oliger, L. (1925): Vita e Diarii del Card. L. Cozza. In: G. Golubovich (ed.): Biblioteca Bio-Bibliografica della Terra Santa e dell'Oriente Francescano, II Serie, Documenti 3., Quaracchi, Roma.

PARMA, L. da (1893): Általános Rendelkezések a Szentföldi Kusztódia Nagyobb Hasznára.

PIANA, C. (1944): Le relazioni della Custodia di Terra Santa con la Chiesa Orientale negli anni 1762-1767. Archivum Franciscanum Historicum, 37: 48-87. [Csak 1947-ben publikálták.]

Piacenza, P. (1765): Papíralapú kézirat. vols. 1-2., [lelőhely: Szent Katalin kolostor, Bologna].

PUERTO, F. (1724): Patrimonio Seraphico de Tierra Santa. Madrid.

QUARESMI, F. (1880): Historica, Theologica et Moralis Terrae Sanctae Elucidatio. vol. 1., Venetiis.

QUARESMI, F. (1881): Historica, Theologica et Moralis Terrae Sanctae Elucidatio. vol. 2., Venetiis.

Razzoli, R. (1909): I Francescani in Oriente. Tip. di Terra Santa, Jerusalem.

RocchetTA, A. (1630): Peregrinatione di Terra Santa. Alfonzo Dell'Isola, Palermo.

Verniero, P. (1929): Croniche ovvero Annali di Terra Santa. vol. 1. In: G. Golubovich (ed.): Biblioteca BioBibliografica della Terra Santa e dell'Oriente Francescano, II Serie, Documenti 6., Quaracchi, Roma.

Verniero, P. 1930): Croniche ovvero Annali di Terra Santa. vol. 3. In: G. Golubovich (ed.): Biblioteca BioBibliografica della Terra Santa e dell'Oriente Francescano. II Serie, Documenti 8., Quaracchi, Roma.

VERnIERo, P. (1936): Croniche ovvero Annali di Terra Santa. vol. 4. In: G. Golubovich (ed.): Biblioteca BioBibliografica della Terra Santa e dell'Oriente Francescano. II Serie, Documenti 9., Quaracchi, Roma.

WADDING, L. (1935): Annales Minorum. vol. 17., Quaracchi, Roma.

Acta Custodiae Terrae Sanctae (1959). 4. 
Acta Custodiae Terrae Sanctae (1960). 5.

Acta Custodiae Terrae Sanctae (1962) 7.

Atti Discretoriali. Reg. K/R, 107.

Atti Discretoriali. Reg. K/R 1913, 190, 221.

Atti Discretoriali. Reg./B, 13.

Atti Discretoriali. Reg. K/Ab, 230.

Codice A, 16. fol.

Diarium Terrae Sanctae (1909-1912). Jerusalem.

Patrimonio Seraphico de Tierra Santa (1724). Madrid.

Prospectus locorum et Religiosorum Ordinis Minorum S. Francisci Custodiae Terrae Sanctae (1868). Typis Conventus SS. Salvatoris, Jerusalem.

Registro de Religiosi morti in questa Santa Custodia (ms.).

Registro delle Congregazioni dal 1846 al 1855 (ms.).

Status Descriptivus Custodiae Terrae Sanctae anno Domini MCMXXII iussu et auctoritate Rev.mi P. Ferdinandus Diotallevi totius Terrae Sanctae Custodis digestus (1924). Jerusalem.

Status personalis Religiosorum in Alma Seraphica T. S. Custodia actualiter degentium juxta peractam dispositionem in Intermedia Custodiali Congregatione die XXVII, Septembris (1882). Hierosolymis habita. 